\title{
Morphology, physical, chemical and functional properties of starches from cereals, legumes and tubers cultivated in Africa: A review
}

M. Naushad Emmambux * and John R N Taylor

*Corresponding author

Department of Food Science

University of Pretoria

Old Agricultural Building (Building 46)

Lynwood Road

Private bag $\times 20$ Hatfield,

0028 Pretoria, Republic of South Africa,

Tel: + 27124202059

Fax: + 27124202839

Email: naushad.emmambux@up.ac. 


\begin{abstract}
In Africa a variety of indigenous cereals, legumes and tubers are cultivated as starchy food crops. These include sorghum, millet species including pearl millet, finger millet, teff and white and black fonio, and African rice as cereals; cowpea, Bambara groundnut, African yambean and West African locust bean as legumes; and Zulu round potato and the Livingstone potato as tubers. Many of these plants are considered as 'lost crops of Africa'. This paper critically reviews the literature on the physical, chemical, and functionality of their starches. Information is essentially limited to the native starches of sorghum, some millets and cowpea. Livingstone potato starch information is essentially absent. Notable characteristics of African starches include that teff and finger millet have compound starch granules.. Some of the starches have unique properties which could be valuable. The very small granular size of teff and its functional properties can be exploited as a fat replacer. The high retrogradation of cowpea starch has potential in gluten-free pasta and noodles. Nonfood applications for the African starches should be considered in the growing mining and oil industries in Africa.
\end{abstract}

Key words: indigenous African starches, sorghum, millet, fonio, African rice, cowpea, Bambara groundnut, African yambean, West African locust bean, Zulu round potato, Livingstone potato 


\section{Introduction}

The starchy crops cultivated in Africa are tubers (189 M tons), cereals (156 M tons), banana/plantain (27 M tons) and pulses (12 M tons) [http://faostat.fao.org]. Banana/plantain and most of the tubers originated in elsewhere in the world, and their starches have been comprehensively reviewed [1]. Africa, however, is the home to many indigenous cereals, legumes and some tubers, the so-called "lost crops" of Africa [2, 3]. The cereals are sorghum, several millet species including pearl millet, finger millet, teff and white and black fonio, and African rice [2] (Table 1). The major legume species are cowpea, Bambara groundnut, African yambean and West African locust bean [3]. The tubers include the Zulu round potato and the Livingstone potato [3]. Thus, this review will focus on the starches of these indigenous African cereal, legume and tuber crops, as although some have most interesting properties, information on their starches has not been collated, nor for that matter in many cases have their starches been investigated in detail.

The review will look briefly at the cultivation in Africa of each of the cereals, legume and tuber species, shown in Table 1, their general composition, current uses and any particular issues with respect to extraction of their starch. Next, the morphology and composition their starch granules and composition of their starches will be examined. Then, the functionality of the various starches will be reviewed and compared with commercial starches. Lastly, the potential of the African grain starches for commercial use will be examined and research needs identified.

\section{Cultivation, grain characteristics and current uses}

Sorghum production in Africa, approx. $21 \mathrm{M}$ tons (Table 1), is similar to that of wheat and rice and about one-third of maize, which is quantitatively the most important cereal [http://faostat.fao.org]. Sorghum is cultivated all across the continent, with significant quantities being produced in 43 African countries. Nigeria is the largest producer of sorghum, with an annual production of approx. 4.8 $\mathrm{M}$ tons, followed by Ethiopia $3 \mathrm{M}$ 
Table 1. Names and production aspect of African cereal, legumes and tubers

\begin{tabular}{|c|c|c|c|c|c|}
\hline $\begin{array}{l}\text { Generally } \\
\text { used English } \\
\text { name }\end{array}$ & $\begin{array}{l}\text { Other common } \\
\text { vernacular names }\end{array}$ & Scientific name & $\begin{array}{l}\text { Production in } \\
\text { Africa (tons x } \\
1000 \text { ) }\end{array}$ & $\begin{array}{l}\text { Africa \% of } \\
\text { world } \\
\text { production }\end{array}$ & $\begin{array}{l}\text { Major producing countries in } \\
\text { Africa (in descending order) }\end{array}$ \\
\hline Sorghum & $\begin{array}{l}\text { Milo, Kaoliang, Jowar, } \\
\text { Sorgo, Mabela, Mtama }\end{array}$ & $\begin{array}{l}\text { Sorghum bicolor (L.) } \\
\text { Moench }\end{array}$ & 21108 & 38 & $\begin{array}{l}\text { Nigeria, Ethiopia, Sudan, } \\
\text { Burkina Faso }\end{array}$ \\
\hline Pearl millet & $\begin{array}{l}\text { Bulrush millet, Cattail } \\
\text { millet, Mil africain, } \\
\text { Babala, Bajra/Bajira }\end{array}$ & $\begin{array}{l}\text { Pennisetum glaucum (L.) } \\
\text { R. Br. }\end{array}$ & 11700 & 55 & $\begin{array}{l}\text { Nigeria, Niger, Mali, Burkina } \\
\text { Faso }\end{array}$ \\
\hline Finger millet & Ragi, Wimbi & $\begin{array}{l}\text { Eleusine coracana (L.) } \\
\text { Gaertn. }\end{array}$ & 1400 & 23 & Uganda, Ethiopia \\
\hline Teff & Tef, Teff grass & $\begin{array}{l}\text { Eragrostis tef (Zuccagni) } \\
\text { Trotter }\end{array}$ & 1700 & $>90$ & Ethiopia, Eritrea \\
\hline White fonio & $\begin{array}{l}\text { Fonio, Acha, Fonio } \\
\text { millet, Hungry rice }\end{array}$ & $\begin{array}{l}\text { Digitara exilis (Kippist) } \\
\text { Stapf }\end{array}$ & 529 & 100 & Guinea, Mali, Nigeria \\
\hline Black fonio & Black acha, Hungry rice & Digitara iburua Stapf & & & \\
\hline African rice & & Oryza glaberrima Steud. & No data & 100 & Senegal, Sierra Leone \\
\hline Cowpea & $\begin{array}{l}\text { Black eyed pea,Long } \\
\text { bean, Niébé }\end{array}$ & $\begin{array}{l}\text { Vigna unguiculata (L.) } \\
\text { Walp. }\end{array}$ & 5336 & 95 & Nigeria, Niger, Burkina Faso \\
\hline $\begin{array}{l}\text { Bambara } \\
\text { groundnut }\end{array}$ & Bambara bean, Jugo bean & $\begin{array}{l}\text { Vigna subterranea (L.) } \\
\text { Verdc. }\end{array}$ & 149 & 100 & $\begin{array}{l}\text { Burkina Faso, Niger, Mali, } \\
\text { Cameroon }\end{array}$ \\
\hline $\begin{array}{l}\text { African } \\
\text { yambean }\end{array}$ & Haricot igname & $\begin{array}{l}\text { Sphenostylis stenocarpa } \\
\text { (Hochst. ex A. Rich.) } \\
\text { Harms }\end{array}$ & No data & 100 & Nigeria \\
\hline $\begin{array}{l}\text { West African } \\
\text { locust bean }\end{array}$ & Néré & $\begin{array}{l}\text { Parkia biglobosa (Jacq.) } \\
\text { R. Br. ex G. Don }\end{array}$ & $>200$ & 100 & $\begin{array}{l}\text { Nigeria, Benin, Burkina Faso, } \\
\text { Ghana, Togo }\end{array}$ \\
\hline $\begin{array}{l}\text { Zulu round } \\
\text { potato }\end{array}$ & $\begin{array}{l}\text { Hausa potato, } \\
\text { Madagascar potato, } \\
\text { Sudan potato, Fra-fra } \\
\text { potato }\end{array}$ & $\begin{array}{l}\text { Solenostemon } \\
\text { rotundifolius (Poir.) J. K. } \\
\text { Morton, or Plectranthus } \\
\text { rotundifolius (Poir.) } \\
\text { Spreng. }\end{array}$ & - & - & - \\
\hline $\begin{array}{l}\text { Livingstone } \\
\text { potato }\end{array}$ & Wild potato & $\begin{array}{l}\text { Plectranthus esculentus N. } \\
\text { E. Br. }\end{array}$ & - & - & - \\
\hline
\end{tabular}

- Data not available; Sources: http://faostat.fao.org, www.ars-grin.gov 
tons. Sorghum, which is noted for its drought-tolerance, comes into its own in semi-arid regions, as it requires a minimum of $400 \mathrm{~mm}$ of rain for cultivation, unlike maize which requires 500-600 mm of rain [4]. Sorghum agriculture in Africa is characterized by the increasing use of hybrids and improved open pollinating varieties (OPVs), although many subsistence-type farmers still use traditional landraces (Dr M. Chisi, sorghum breeder, Zambia, pers. comm.). The sorghum grain is approximately the same size as wheat, with a 1000 kernel weight of around 25-35 g [5]. Sorghum varieties are highly varied in colour, from white, through bronze, to red and even almost black, due the presence of anthocyanidin pigments in the pericarp [6]. Some sorghum varieties also contain condensed tannins (proanthocyanidins or procyanidins), which are located in the testa layer. However, grain colour is not directly associated with their presence. The starch content of sorghum is on average some 65.7-70.8\% (dry basis) [5, 7]. As in all cereals, the starch granules are located in the starchy endosperm. Uniquely, however, the pericarp of sorghum also contains starch granules [5].

Sorghum is by far the most economically important indigenous cereal in Africa. It is used on large scale for industrial and community malting and brewing of traditional opaque and cloudy beers, and as a staple food in the form of porridges and flatbreads [8]. In Nigeria, in the past three decades a very large malting and brewing industry has been created to produce lager and stout beers and non-alcoholic beverages based on sorghum [9]. There is also industrial lager beer brewing using sorghum in East and Southerncentral Africa. In Sudan and in the USA there has been industrial wet milling of sorghum for starch extraction. However, this is no longer taking place. Sorghum wet milling is more complicated than maize wet milling [10]. The pericarp of sorghum is more friable and small pieces impede starch and protein separation and discolour the starch. As a result, the starch must be bleached to remove the anthocyanin pigments, as these pigments strongly bind with the starch [11].

Pearl millet is by quantitatively by far the most important of the millets cultivated in Africa. Production is mainly in the Sahel region, the Horn of Africa and the dry southwest of the continent. Nigeria is also the major producing country with an annual 
production of approx. 4.1 M tons (Table 1), followed closely by Niger

[http://faostat.fao.org]. Pearl millet is the most arid-tolerant cereal and can be cultivated with as little as $300 \mathrm{~mm}$ of rain [4]. Pearl millet agriculture in Africa is today characterized by the increasing use of improved OPVs (Chisi pers. comm.). The pearl millet grain is about the one-third the size of sorghum and ranges in colour from white, buff to grey [5]. It is rich in polyphenols but does not contain tannins. The starch content is on average some $71.6 \%$ (dry basis) [5]. In Africa, pearl millet is widely used for community malting and brewing of traditional opaque beer and as a staple food in the form of porridges and couscous. It is used industrially for malting and couscous production on a limited scale.

Concerning the other millets, finger millet production is greatest in East and centralsouthern Africa. It requires higher rainfall than pearl millet, although has the advantage that the grain stores well [12]. There has been limited finger millet breeding. The finger millet grain is about a tenth the size of sorghum. Like sorghum, finger millet is highly variable in colour, from brown through red to white, due to anthocyanin pigments and also like sorghum some varieties contain tannins in the testa layer [13]. Data on its starch content are limited, with figures of 55.1\% (dry basis) being given for starch [5] and 74\% (dry basis) for carbohydrate [2]. Finger millet is malted for traditional fermented beverages and it is used also consumed in the form of porridges and flatbreads.

Teff production is by far the greatest in Ethiopia and Eritrea, with some being produced in South Africa. Teff thrives at high elevation (optimum $2000 \mathrm{~m}$ ), can be grown in a wide range of soils and under rainfall conditions [12]. In Ethiopia, there is an extensive breeding programme for improved OPVs (Dr S. Yetneberk, cereal scientist, Ethiopia, pers. comm.). The teff grain is tiny with a 1000 kernel weight of about $2 \mathrm{~g}$ [14]. Teff is also high variable in colour, from brown to white but there do not seem to be tannin containing varieties. The starch content is approx. 73\% [14]. By far the major use for teff is for injera, a fermented flatbread and the staple food in Ethiopia. 
Fonio cultivation is exclusively in the arid Sahel region as a subsistence crop, with by far the greatest production in Guinea (400 000 tons) [http://faostat.fao.org]. The fonio grain is even smaller than that of teff with a 1000 kernel weight of approx. $0.4 \mathrm{~g}$ [15] but is enclosed in a thick hull that must be removed before consumption. The white and black species are similar except for the darker colour of the latter, which appears to be due to phenolics. The carbohydrate content is approx. $75 \%$ (dry basis). Fonio is used in a wide range of traditional foods and beverages.

African rice is cultivated on a small scale in tropical West Africa as a substance crop [2]. It has been crossed with conventional rice (Oryza sativa (L.) to produce a new type of rice called NERICA, which stands for new rice for Africa. NERICA is well adapted to economic cultivation throughout tropical Africa and has good nutritional value [www.warda.cgiar.org]. Both African rice and NERICA resemble conventional rice and are consumed in the same way. African rice has a carbohydrate content of approx. 81\% (dry basis) [2].

Cowpea is the commonly cultivated pulse in Africa. The production of $5.3 \mathrm{M}$ tons is rather higher that of common beans (Phaseolus vulgaris (L.) [http://faostat.fao.org]. Significant quantities of cowpea are produced in 19 countries across the continent, with the highest production being in Nigeria (2.2 M tons) and Niger (1.8 M tons). Some breeding of improved varieties is taking place, although the use of traditional landraces remains common (Prof A. Minnaar, Dry Grain Pulses CRSP Scientist, University of Pretoria, South Africa). Cowpeas are 5-12 mm long, kidney shaped and range widely in colour from white, through to yellow, red, brown, or black, with some being speckled or blotched [3]. It is the seedcoat (hull) that is coloured with the pigmentation being due to flavonoids [16], although the pigments can also colour the cotyledons somewhat. The starch content is approx. 37\% [17] and as in all legumes the starch granules are located in the cotyledon cells. In Africa the major uses for cowpeas are as beans and in the form of pastes such as akara (fried) and moinmoin (steamed) [3]. 
Bambara groundnut, like cowpeas, is cultivated across Africa almost exclusively as a subsistence crop. The major production is in West Africa with Burkina Faso being the major producing country (59 000 tons) [http://faostat.fao.org]. Bambara is droughttolerant and can be cultivated in poor soil [3]. However, there has been little breeding to improve landraces. The seeds are roundish, 11-15 $\mathrm{mm}$ and vary in colour from cream, through red to black, with some types being speckled [3]. The starch content is approx. 48\% (dry basis) [18]. In Zimbabwe, Bambara has been canned commercially, but mostly they are eaten as nuts, or flour is made into a fritter type product [19].

The African yambean is cultivated as a subsistence crop in West Africa (primarily Nigeria) central Africa, east Africa and as far south as Zimbabwe [3]. It thrives in environments where there is heavy rainfall and poor soil. However, essentially no crop improvement has taken place. The seeds are round to kidney shaped (9 x $7 \mathrm{~mm}$ ) and vary in colour from brown, white, speckled or marbled [20]. The carbohydrate content is approx. $61.6 \%$ [21]. It is mainly eaten as a bean.

The West African locust bean is actually a tree. It grows in a band from West Africa, across central Africa [3]. The seeds are 5-15 mm and dark brown in colour [www.prota.org]. It has a carbohydrate content of approx. 60\% (dry basis) [22]. The boiled, fermented and dried seeds are used a savoury condiment [3].

The Zulu round potato and the Livingstone potato are two related tuber species, uniquely for tubers belonging to the mint (Lamiaceae) family [www.ars-grin.gov]. The Zulu round potato requires regular water and well-drained soil. It is cultivated across Africa's tropical lowlands $[3,19]$. The Livingstone potato is highly adaptable and can be grown in almost any climatic zone, provide also that there is regular rainfall and well-drained soil $[3,19]$. It is cultivated more in Eastern and southern Africa. Both are subsistence crops in Africa. However, the Zulu round potato is also cultivated in tropical Asian countries such as Sri Lanka and has been subject to crop improvement and breeding [23]. The Zulu round potato tubers are smaller than Irish potatoes, rounded or oblong and dark brown to black in colour $[19,23]$. Its carbohydrate content is approx. 89.8\% (dry basis) 
(21.9\% as is basis) [24]. Those of the Livingstone potato are thinner and finger-like and white or yellowish [3, 19]. Its carbohydrate content is approx. 83.4\% (dry basis) (16.7\% as is basis) [25]. Both are mostly consumed cooked as vegetables.

\section{Granule morphology}

Sorghum starch granules are of the simple (individual type) but have two morphologies. Those from the outer dense corneous (horny, hard) endosperm are polygonal in shape and often dented (dimpled) [63] (Table 2, Fig. 1B). The shape is due to their tight packing and the denting (golf ball-like dimples) due to protein bodies pressing in them. In contrast, the starch granules from the inner less dense floury (soft) endosperm are more spherical without dents (Fig. 1A). The difference is presumably because the latter can grow freely. Sorghum starch granules are visually indistinguishable from those of maize, which also has a corneous and floury endosperm, although they may possibly be larger [66]. As with maize, sorghum starch granules have pores on their surface [67], leading to channels to a central cavity in the starch granules [68]. It has been found the density of channels was higher in a high digestibility sorghum mutant and that a portion of starch granules in the mutant had a unique "doughnut” shape [31]. The starch granules of the waxy (high amylopectin) sorghum mutant are indistinguishable from those of normal sorghum, although there may not be dimpled types [64].

Concerning the millets, the starch granules of pearl millet are similar in appearance to those of sorghum but seem to be somewhat smaller (Table 2) [41]. Like sorghum, they have the same two morphologies (Fig. 1C, D), as pearl millet also has an outer corneous and inner floury endosperm. In contrast to sorghum and pearl millet, finger millet has both simple and compound starch granules (Fig. 1E, F) [41], with considerable variations in both size and shape (Table 2). Teff, which is closely related to finger millet, both belonging to the Eragrostideae tribe [www.ars-grin.gov], only seems to have compound starch granules (Fig. 2A ), comprising small (2-6 $\mu \mathrm{m}$ ) polygonal granules (Fig. 2B) [43, 69]. The granules have neither surface pores, nor channels in them [43]. The starch granules in white and black fonio are simple, but small (average 6-8 $\mu \mathrm{m}$ ) and polygonal 

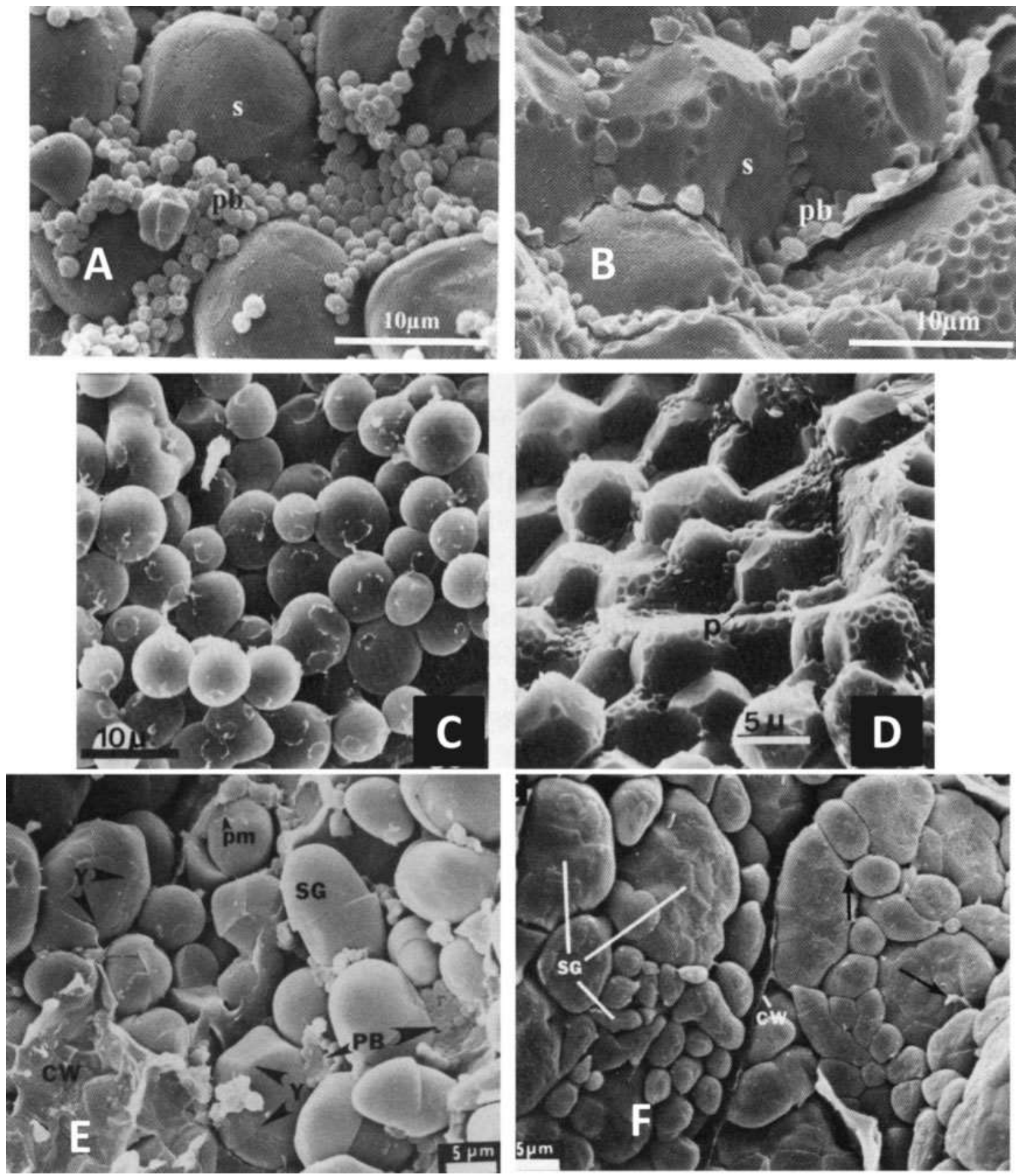

Figure 1. Scanning electron micrographs of sorghum, pearl millet, and finger millet starch granules.

(A) Sorghum floury endosperm,

(B) sorghum corneous endosperm;

(C) pearl millet floury endosperm,

(D) pearl millet corneous endosperm [66];

(E) finger millet simple granules,

(F) fingermillet compound granules [41]. cw, cellwall; p/pb, protein bodies; pm, protein matrix; s/sg, starch granules; $y$, starch granule subunits. 
Table 2. African cereal, legume and tuber starch granule morphology and composition

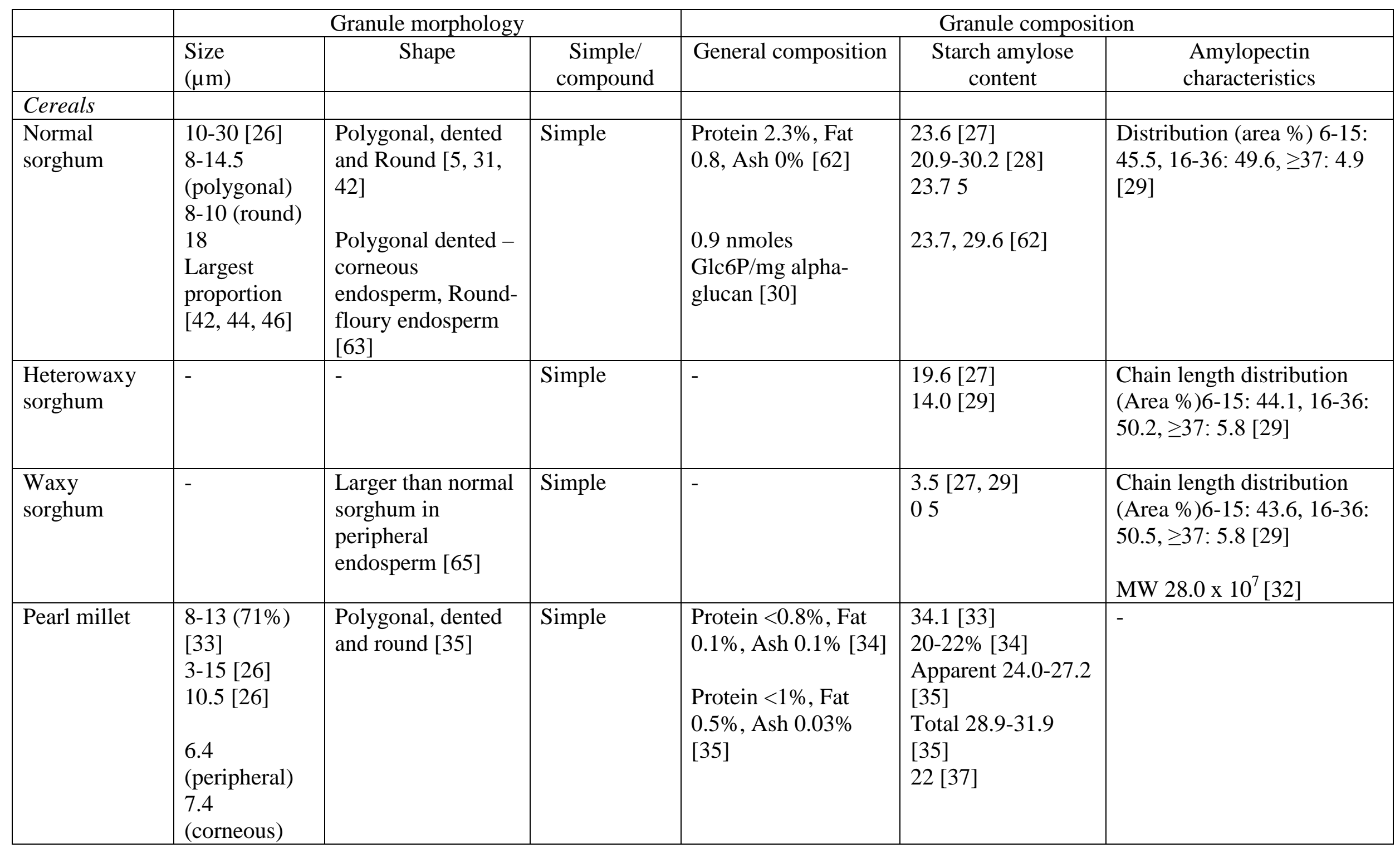




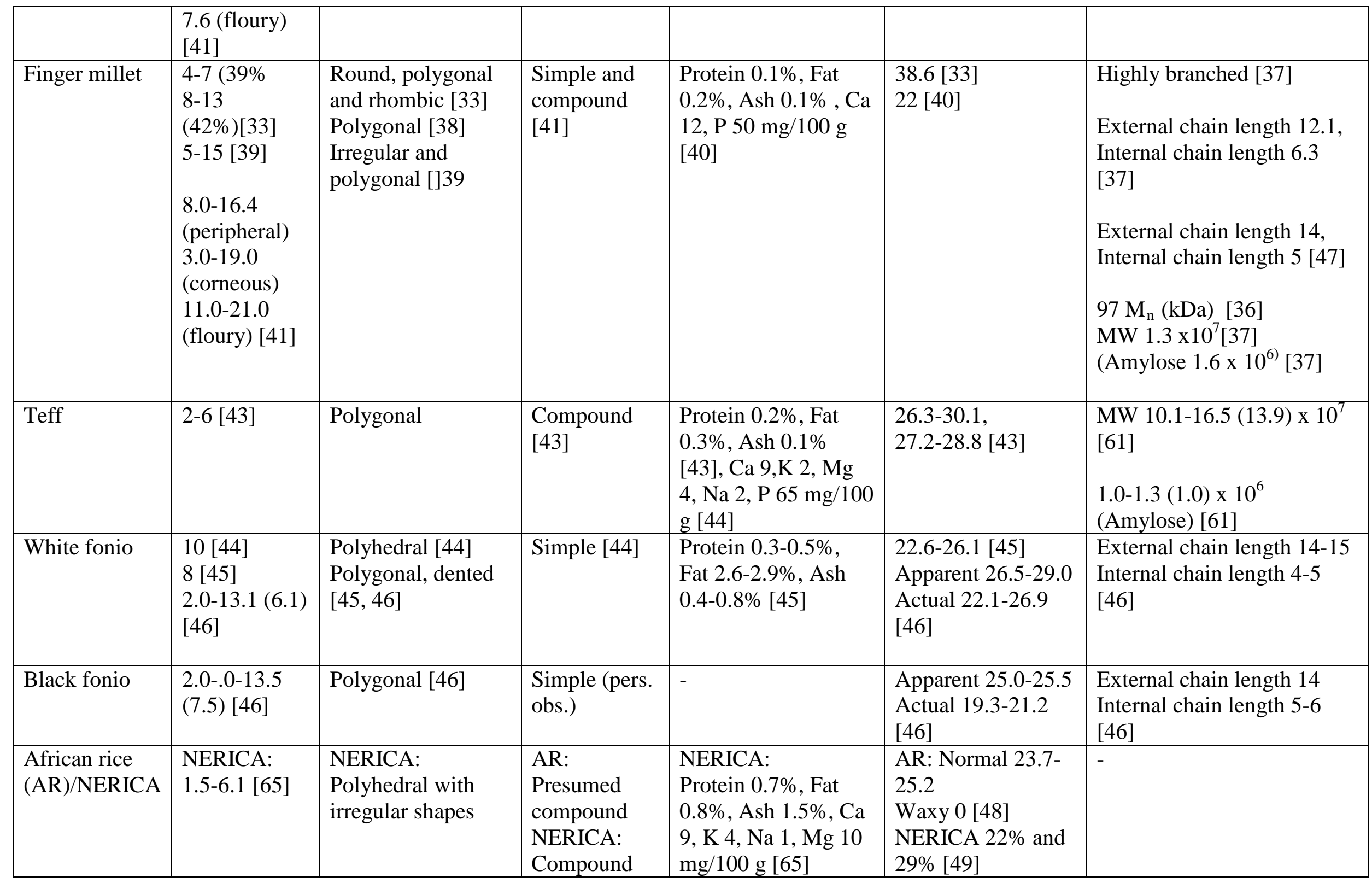




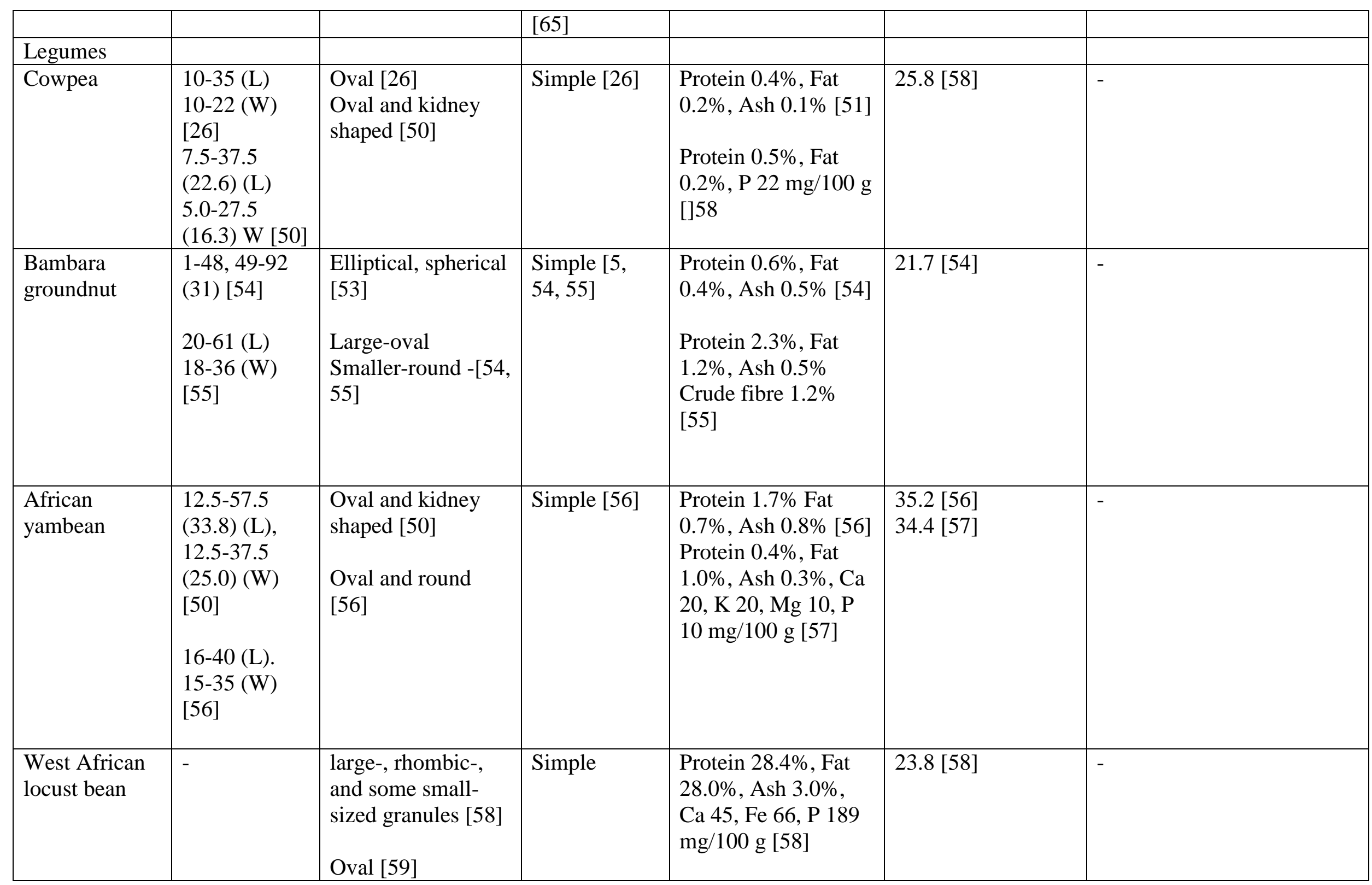




\begin{tabular}{|l|l|l|l|l|l|l|}
\hline Tubers & & & & & \\
\hline $\begin{array}{l}\text { Zulu round } \\
\text { potato }\end{array}$ & $8-25[23]$ & $\begin{array}{l}\text { Dome shaped and } \\
\text { hemispherical with } \\
4-5\end{array}$ & $\begin{array}{l}\text { No clear } \\
\text { information } \\
\text { slightly concaved } \\
\text { facets [23] }\end{array}$ & $\begin{array}{l}\text { Protein 0.1\%, Ash } \\
0.1 \%, \text { P 90-100 } \\
\text { mg/100 g [23] }\end{array}$ & $\begin{array}{l}\text { Apparent 16.3, } \\
\text { 23.0 } \\
\text { Total } \\
18.7,25.2 ~[23]\end{array}$ & $\begin{array}{l}\text { Average chain length } \\
\text { distribution 6-12: 25.1, 13- } \\
\text { 24: 54.5, 25-36: 16.2, 37-50: } \\
4.3 \text { [23] }\end{array}$ \\
\hline $\begin{array}{l}\text { Livingstone } \\
\text { potato }\end{array}$ & $\begin{array}{l}\text { 9.5-44.5 } \\
\text { (20.2) [60] }\end{array}$ & $\begin{array}{l}\text { Spherical and } \\
\text { polyhedral [60] }\end{array}$ & $\begin{array}{l}\text { No clear } \\
\text { information }\end{array}$ & & 24.0 [60] & - \\
\hline
\end{tabular}

- Data not available 


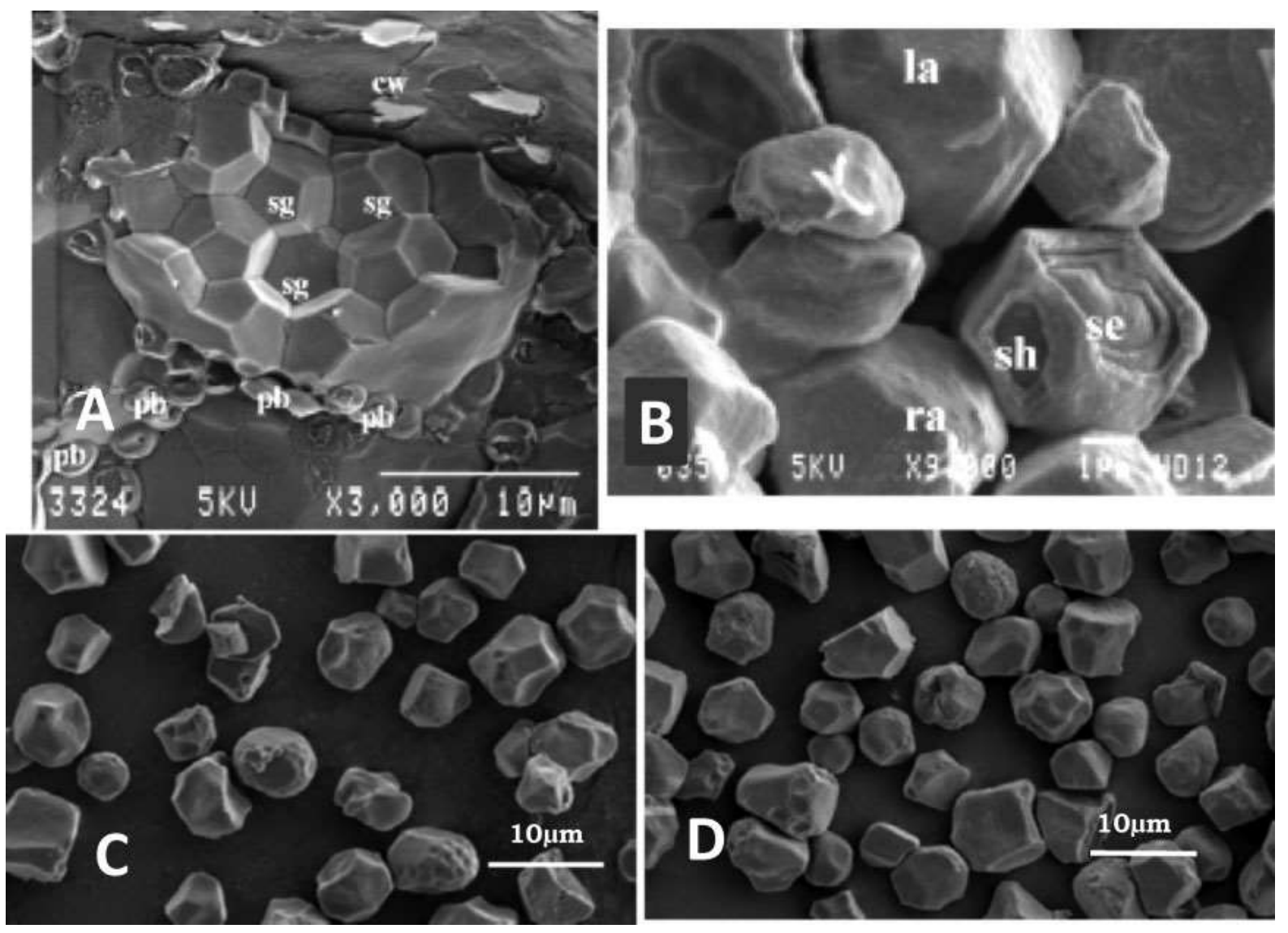

Figure 2. Scanning electron micrographs of teff and fonio starch granules.

(A) Teff compound granule [43];

(B) teff individual granules partially digested by alpha-amylase [69];

(C) white fonio;

(D) black fonio.cw, cell wall; pb, protein bodies; sg, starch granules; la, less attacked; ra, raw; se, surface erosion; sh, surface eroded hole. 
shaped (Table 2 [47]) and essentially indistinguishable between the two species (Fig. 2C,D).

African rice starch granules do not seem to be been described. However, when they were isolated at the same time as common rice [48], as no mention is made of any difference, it is presumed that they are compound, like those of common rice [66] and NERICA [65].

The starch granules of cowpea, Bambara groundnut and yambean and generally oval or elliptical in shape and very variable in size (Fig. 3A, B, D, Table 2), and are typical of legume starch granules [26]. With Bambara groundnut, it appears that the smaller granules tend to be more round $[54,55]$ (Fig. 3B). Locust bean starch granules are described as being variously oval [59] and large-, rhombic-, and some small-sized granules [58]. However, the available micrographs are too indistinct to draw any firm conclusions [58].

The starch granules of Zulu round potato are dome shaped and hemispherical with several slightly concaved facets [23] (Fig. 3C). In these respects and their smaller size (8-25 $\mu \mathrm{m})$, they differ substantially from those of conventional Irish potato [26]. This is perhaps not surprising as, as stated, the Zulu round potato belongs to the mint family (Lamiaceae) and the potato the Solanaceae family [www.ars-grin.gov]. It is also noted that the surface of the starch granule from Zulu round potato appears to have many pores [23] (Fig. 3C). The starch granules of Livingstone potato [60] have a similar morphology to those of Zulu round potato.

\section{Granule composition}

Normal sorghum has a typical proportion of amylose, on average around 24\% (Table 2).

This decreases progressively with in heterowaxy and waxy types [27, 29], with increasing dosage of the recessive waxy allele [29]. The proportion of shorter chain length amylopectin (DP 6-15) appears to be slightly higher in normal sorghum, compared to the heterowaxy and waxy mutants [29]. 

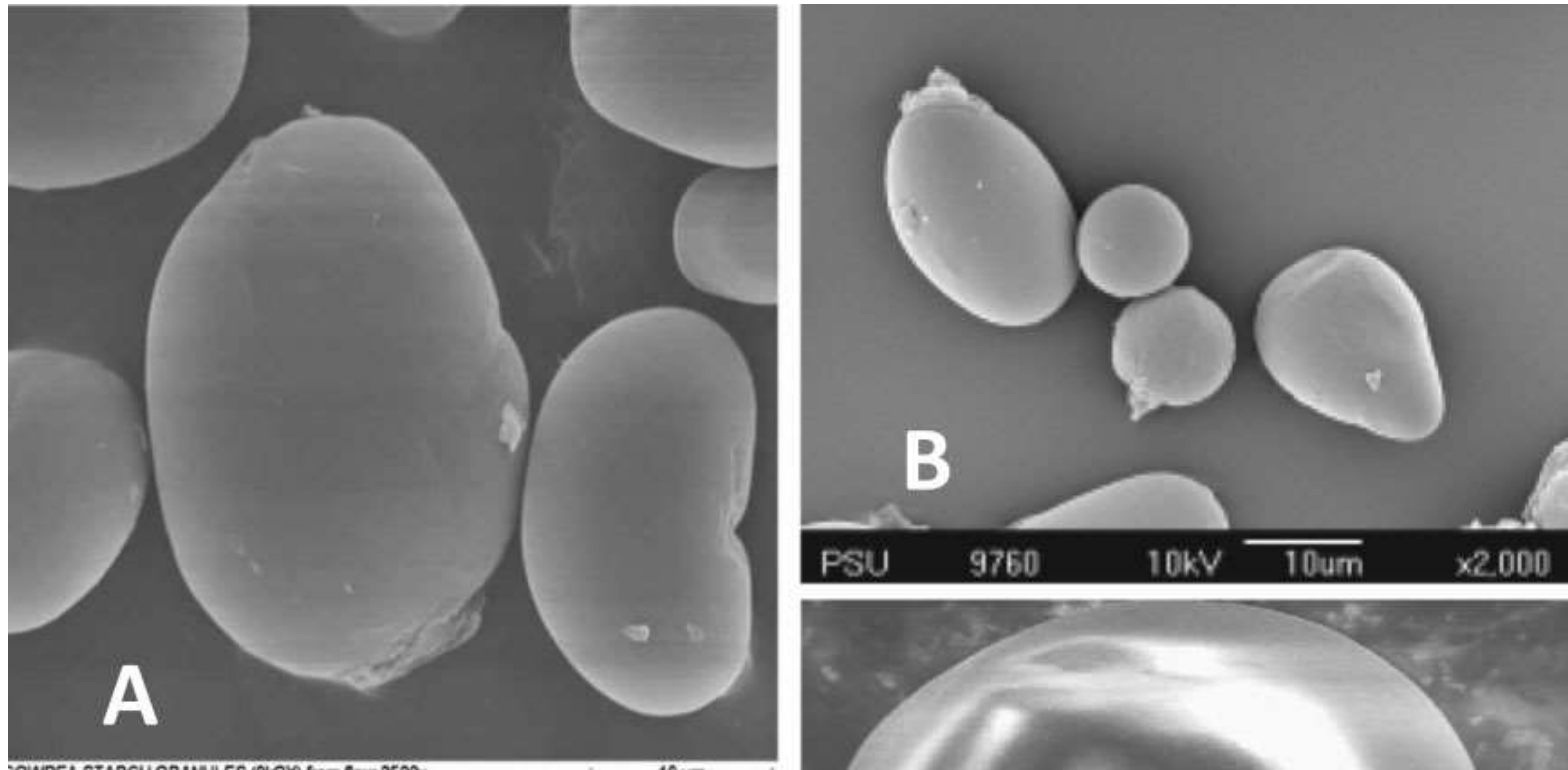

ZOWPEA STARCH GRAWULES (OKGY from flour 2500x
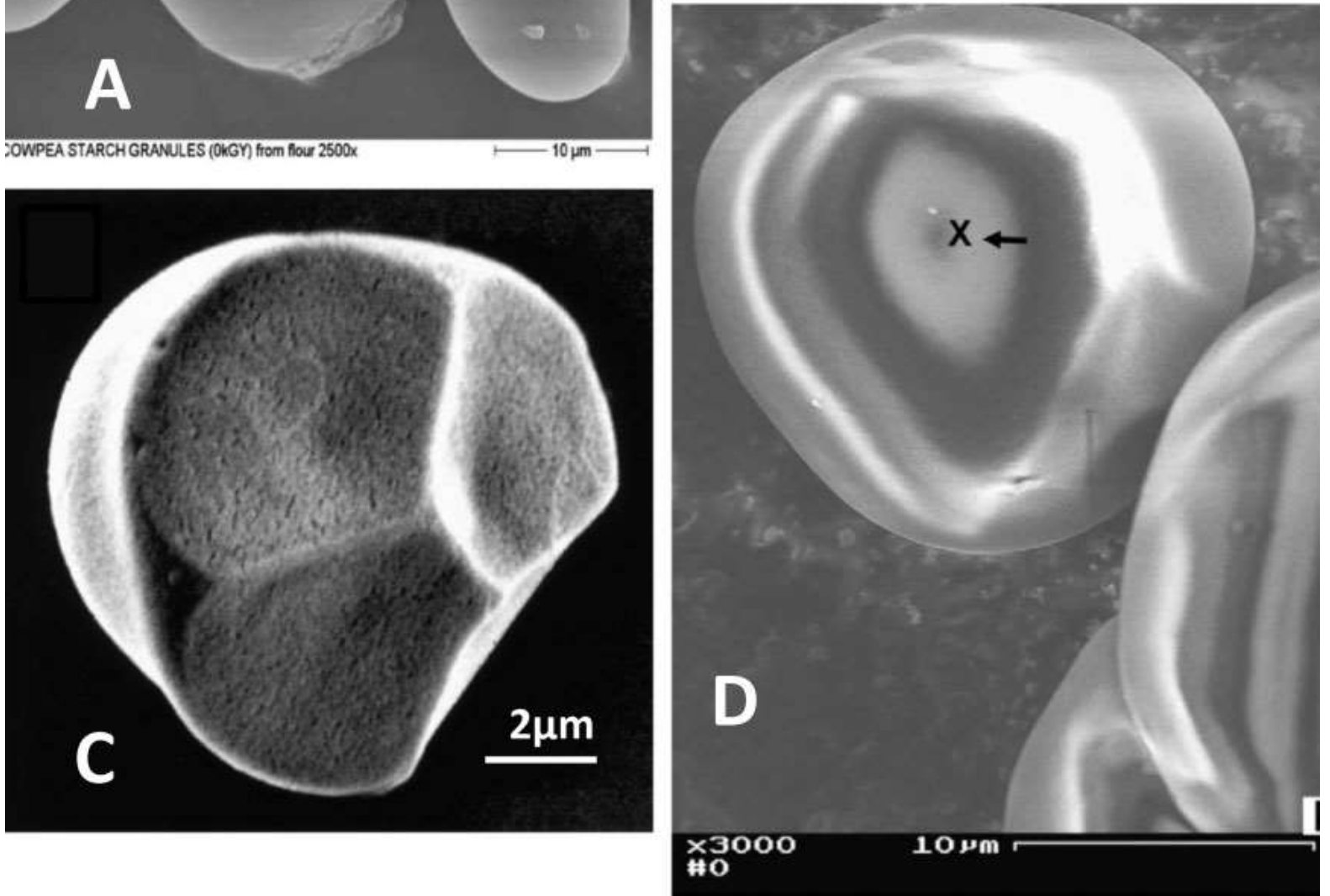

Figure 3. Scanning electron micrographs of cowpea, Bambara, Zulu round potato starch granules, and yambean starch granules.
(A) Cowpea [85];
(B) Bambara [54];
(C) Zulu round potato [23];
(D) yambean [56]. $x$, surface indentation. 
With regard to the millets, the amylose content of pearl millet, teff and fonio starches are in the normal range (Table 2). The limited data on finger millet amylose content appears contradictory. Malleshi et al. [33] reported a very high value of 38.6\%, but more recently Mohan et al. [40] reported a normal value of 22\%. According to data from Singh and Ali [36], the molecular weight of finger millet starch is lower than that of other starches such as maize, chick pea and potato. This is agreement with data from Madhusudhan and Tharanathan [37] giving an amylopectin molecular weight of $1.3 \times 10^{7}$, in comparison with values of $28.0 \times 10^{7}$ [32] for waxy sorghum and $13.9 \times 10^{7}$ for teff [61] (Table 1). However, finger millet amylopectin chain lengths external 12-14, internal 5-6 [37, 47] seem to be same as those reported by for white and black fonio, 14-15 (external), and 4-6 (internal) [47] (Table 2). In terms of teff starch granule composition, the phosphorus content (average $65 \mathrm{mg} / 100 \mathrm{~g}$ ) was found to be about twice that of maize starch, but apparently similar to rice starch [44].

Concerning amylose levels in African rice and NERICA starches, there are both normal and waxy types of African rice [48]. With NERICA, the amylose content seems to depend on whether the genotype contains the granule-bound starch synthase I from African rice or common rice [49]. The amylose content is rather higher in the former case (approx. 29\%).

Bambara groundnut has a low amylose content for a legume of 21.7\% [54]. The higher amylose contents of the cowpeas (26\%) and yambean (35\%) (Table 2) are more typical of pulse starches, which typically contain $>30 \%$ amylose [35]. The available data for locust bean starch granule composition may be anomalous as they indicate a very protein content of 28\% (Table 2 [58]).

Both the Zulu round potato and the Livingstone potato starches have a normal amylose content $\leq 25 \%$ (Table 2). The Zulu round potato amylopectin chain length pattern was found to resemble that of waxy maize [23]. 
Table 3. X-ray diffractogram peaks and relative crystallinity \% of starches from African cereals, legumes and tubers

\begin{tabular}{|c|c|c|c|c|c|}
\hline & & $\begin{array}{l}\text { XRD } \\
\text { pattern }\end{array}$ & $\begin{array}{l}\text { Main peaks } \\
\text { ( } 2 \theta \\
\text { degrees) }\end{array}$ & $\begin{array}{l}\text { Relative } \\
\text { crystallinity }\end{array}$ & References \\
\hline Cereals & $\begin{array}{l}\text { Variety, } \\
\text { Country }\end{array}$ & & & & \\
\hline \multirow[t]{5}{*}{ Sorghum } & $\begin{array}{l}\text { Mota Maradi, } \\
\text { Nigeria }\end{array}$ & A & NS & 26.2 & \multirow[t]{3}{*}[71]{} \\
\hline & $\begin{array}{l}\text { SC283-14, } \\
\text { USA }\end{array}$ & A & NS & 25.5 & \\
\hline & P851171, USA & A & NS & 24.2 & \\
\hline & $\begin{array}{l}\text { White } \\
\text { sorghum, } \\
\text { Algeria }\end{array}$ & A & $\begin{array}{l}15,17,18, \\
23\end{array}$ & 22.7 & \multirow[t]{2}{*}[72]{} \\
\hline & $\begin{array}{l}\text { Red sorghum, } \\
\text { Algeria }\end{array}$ & A & & 28.9 & \\
\hline Pearl millet & $\begin{array}{l}\text { ICTP 8203, } \\
\text { ICMS7703 } \\
\text { and ICMH } 356\end{array}$ & A & $\begin{array}{l}\text { Abt 12.88, } \\
14.58,15.32 \\
\text { and 19.66 }\end{array}$ & ns & [73] \\
\hline \multirow[t]{3}{*}{$\begin{array}{l}\text { Finger } \\
\text { millet }\end{array}$} & $\begin{array}{l}\text { GE 5153, } \\
\text { India }\end{array}$ & A & 15 and 23 & 30.1 & {$[40]$} \\
\hline & NS & A & $\begin{array}{l}15.1,17.6 \\
\text { and } 23\end{array}$ & 33 & {$[74]$} \\
\hline & NS & A & $15,18,23$ & 44 & [75] \\
\hline \multirow[t]{4}{*}{ Teff } & $\begin{array}{l}\text { DZ-01-99, } \\
\text { Ethiopia }\end{array}$ & A & NS & 37 & \multirow[t]{4}{*}[44]{} \\
\hline & $\begin{array}{l}\text { DZ-01-196, } \\
\text { Ethiopia }\end{array}$ & $\mathrm{A}$ & NS & 38 & \\
\hline & $\begin{array}{l}\text { DZ-01-1681, } \\
\text { Ethiopia }\end{array}$ & A & NS & 37 & \\
\hline & DZ-Cr-37, & A & NS & 37 & \\
\hline
\end{tabular}




\begin{tabular}{|c|c|c|c|c|c|}
\hline & Ethiopia & & & & \\
\hline & $\begin{array}{l}\text { South African } \\
\text { Brown }\end{array}$ & A & NS & 37 & \\
\hline \multicolumn{6}{|l|}{ legumes } \\
\hline Cowpea & NS, China & $\mathrm{C}$ & $\begin{array}{l}15.2,17.2, \\
23.2\end{array}$ & & [52] \\
\hline \multirow[t]{2}{*}{$\begin{array}{l}\text { Bambara } \\
\text { groundnut }\end{array}$} & NS & $\mathrm{C}$ & NS & 39 & [76] \\
\hline & NS, Thailand & A & NS & 43.7 & [54] \\
\hline $\begin{array}{l}\text { African } \\
\text { yambean }\end{array}$ & NS & C & $\begin{array}{l}15.2,17.2, \\
22.2,25.2\end{array}$ & 20 & [56] \\
\hline $\begin{array}{l}\text { West } \\
\text { African } \\
\text { locust bean }\end{array}$ & NS, Guinea & $\mathrm{C}$ & NS & & [59] \\
\hline \multicolumn{6}{|l|}{ Tubers } \\
\hline \multirow[t]{2}{*}{$\begin{array}{l}\text { Zulu round } \\
\text { potato }\end{array}$} & $\begin{array}{l}\text { Bola, Sri } \\
\text { Lanka }\end{array}$ & $\mathrm{C}_{\mathrm{a}}$ & $\begin{array}{l}\text { 5.5, 17, 18, } \\
20,23.4\end{array}$ & 40 & \multirow[t]{2}{*}[23]{} \\
\hline & Dik, Sri Lanka & $\mathrm{C}_{\mathrm{a}}$ & $\begin{array}{l}\text { 5.5, 17, 18, } \\
20,23.4\end{array}$ & 37 & \\
\hline
\end{tabular}

$\mathrm{NS}=$ not specified

There is no reported data for white fonio, black fonio, African rice and Livingstone potato 


\section{$5 \mathrm{X}$-ray diffractogram pattern and crystallinity}

Native starch is semi-crystalline. The crystalline portion is mostly a well ordered structure of amylopectin molecules inside the granule. Starches can be classified according to 'A', 'B' or ' $\mathrm{C}$ ' crystalline type pattern. Table 3 shows the type and crystalline structures of African starches and their relative crystallinity. ' $\mathrm{A}$ ' type $\mathrm{X}$-ray diffractogram (XRD) crystalline pattern is mostly characterised with $2 \theta$ values of about 15.3, 17.8 and 23.2; and ' $B$ ' type starches have $2 \theta$ values of about 5.5, 15, 17, 22.2 and 24 [23]. 'C' type starches are combination of ' $A$ ' and 'B' types and typical for legume starches [70]. Most of the African cereal starches are ' $\mathrm{A}$ ' type with relative crystallinity values of about $22-44 \%$. The legume starches are mostly ' $\mathrm{C}$ ' type XRD pattern and shows relative crystallinity from 37-44\% except for African yambean.

It is worth noting that the crystallinity values and the XRD peak intensities of the African starches (Table 3) are generally higher than temperate cereals like wheat [77]. Mohan et al. [40] also found that the finger millet starches have a higher crystallinity values compared to rice starches. Cultivar also seems to affect the crystallinity values. For example, red (polyphenol-rich) sorghum seems to have higher crystallinity values than white sorghum [72]. The higher crystallinity values are related to higher gelatinisation temperatures (Table 4).

Sirivongpaisal [54] reported that Bambara groundnut starches are 'A' type compared to the other legume starches reported to be 'C' type (Table 3), which was consistent with its low amylose content and it having small round starch granules as well as the normal legume large oval type [54,55]. However, the work of Sirivongpaisal did not report the moisture content. Gunaratne and Hoover [78] found that the $5.52 \theta$ values can only be observed above $16 \%$ moisture content. This peak value can change the structure from ' $\mathrm{A}$ ' type to ' $\mathrm{C}$ ' type. Thus, it is possible that the $5.52 \theta$ values was not observed due to a lower moisture content of the starches during XRD analysis. 
Table 4. Thermal properties of starches African cereals, legumes and tubers

\begin{tabular}{|c|c|c|c|c|c|c|c|}
\hline \multirow[b]{2}{*}{ Cereals } & \multirow[b]{2}{*}{ Variety/types } & \multirow{2}{*}{$\begin{array}{l}\text { For DSC: Solid to } \\
\text { moisture ratio; } \\
\text { and heating rate } \\
\left({ }^{\circ} \mathrm{C} / \mathrm{min}\right)\end{array}$} & \multicolumn{3}{|c|}{ Gelatinisation temperatures $\left({ }^{\circ} \mathrm{C}\right)$} & \multirow{2}{*}{$\begin{array}{l} \\
\begin{array}{l}\text { Delta H } \\
(\mathrm{J} / \mathrm{g})\end{array}\end{array}$} & \multirow[t]{2}{*}{ References } \\
\hline & & & $\mathrm{T}_{\mathrm{o}}$ & $\mathrm{T}_{\mathrm{p}}$ & $\mathrm{T}_{\mathrm{e}}$ & & \\
\hline & Waxy & \multirow[t]{3}{*}{$1: 2,10$} & 67.7 & 73.0 & 82.1 & 14.7 & \multirow[t]{3}{*}{ [29] } \\
\hline \multirow[t]{18}{*}{ Sorghum } & Heterowaxy & & 69.6 & 72.8 & 78.6 & 13.7 & \\
\hline & normal & & 67.9 & 70.7 & 75.7 & 13.2 & \\
\hline & $\begin{array}{l}\text { Mota } \\
\text { Maradi,Nigeria }\end{array}$ & \multirow[t]{3}{*}{$1: 2,5$} & 70.1 & 72.6 & 80.3 & 11.5 & \multirow[t]{3}{*}[71]{} \\
\hline & SC283-14, USA & & 61.6 & 67.4 & 75.7 & 9.5 & \\
\hline & P851171, USA & & 61.6 & 66.6 & 76.3 & 9.7 & \\
\hline & NS & $1: 4,5$ & 62.3 & 67.0 & 72.0 & 2.5 & [79] \\
\hline & $\begin{array}{l}\text { White sorghum, } \\
\text { Algeria }\end{array}$ & \multirow[t]{2}{*}{$1: 2,5$} & 66.6 & 70.6 & 76.8 & 9.1 & \multirow[t]{2}{*}[72]{} \\
\hline & $\begin{array}{l}\text { Red sorghum, } \\
\text { Algeria }\end{array}$ & & 68.4 & 72.3 & 77.1 & 8.3 & \\
\hline & M-35, India & $3: 7,10$ & 68.4 & 72.1 & 76.16 & 11.47 & [80] \\
\hline & Katandanzara & \multirow[t]{9}{*}{$1: 2.25,10$} & & $68.0-70.5$ & & $7.0-9.5$ & \multirow[t]{9}{*}{ [28]\# } \\
\hline & Mutode & & & 67.4-71.5 & & 7.3-9.9 & \\
\hline & Chibonda & & & $66.0-69.0$ & & $6.8-9.9$ & \\
\hline & Chirimaugute & & & $67.0-71.0$ & & $7.1-10.7$ & \\
\hline & Kasvikisire & & & $67.0-71.9$ & & $7.1-10.1$ & \\
\hline & Mukadziusaenda & & & $68.4-72.0$ & & 7.7-9.7 & \\
\hline & Mukadzidzoka & & & $66.4-73.0$ & & 7.3-11.1 & \\
\hline & Tsveta & & & $65.6-71.0$ & & 6.8-9.8 & \\
\hline & SV2 & & & $67.1-72.0$ & & 7.9-9.6 & \\
\hline
\end{tabular}




\begin{tabular}{|c|c|c|c|c|c|c|c|}
\hline & DC-75 & & & $68.0-71.0$ & & 7.5-9.8 & \\
\hline \multirow[t]{9}{*}{ Pearl millet } & $\begin{array}{l}\text { HMP1700, } \\
\text { Uganda }\end{array}$ & $\begin{array}{l}\text { Use of kofler hot } \\
\text { stage }\end{array}$ & 59 & 65 & 68.5 & & [34] \\
\hline & $\begin{array}{l}\text { Severe 3A, } \\
\text { Uganda }\end{array}$ & & 61 & 65.5 & 68 & & \\
\hline & HMP 550, Uganda & & 60.5 & 65 & 68 & & \\
\hline & RMP'78, USA & & 63 & 67.5 & 69 & & \\
\hline & RMP'76, USA & & 62 & 67.5 & 70 & & \\
\hline & ICTP 8203 & $1: 3,10$ & 61.2 & 68 & 75 & 11.29 & [73] \\
\hline & ICMS 7703 & & 64.5 & 70 & 78 & 14.6 & \\
\hline & ICMH 356 & & 60.9 & 67.5 & 74 & 10.46 & \\
\hline & NS, Botswana & $2: 7,5$ & 50.6 & 72.2 & 80.2 & 397 & [81] \\
\hline & & & & & & & \\
\hline \multirow[t]{2}{*}{ Finger millet } & GE 5153, India & $1: 10 ; 10$ & 64.5 & 69 & 75 & 9.1 & [40] \\
\hline & NS & $1: 3,10$ & 68.2 & 70.6 & 73.8 & 9.6 & [75] \\
\hline \multirow[t]{3}{*}{ Teff } & $\begin{array}{l}\text { DZ-01-99, } \\
\text { Ethiopia }\end{array}$ & $1: 4,10$ & 66.2 & 71.2 & 91.4 & 5.97 & \multirow[t]{3}{*}{ [44] } \\
\hline & $\begin{array}{l}\text { DZ-01-196, } \\
\text { Ethiopia }\end{array}$ & & 65.0 & 71.3 & 81.5 & 7.59 & \\
\hline & $\begin{array}{l}\text { DZ-01-1681, } \\
\text { Ethiopia }\end{array}$ & & 65.1 & 71.3 & 81.0 & & \\
\hline \multicolumn{8}{|l|}{ legumes } \\
\hline \multirow[t]{2}{*}{ Cowpea } & NS, China & $1: 4, \mathrm{NS}$ & 70.5 & 75.4 & 81.0 & 15.2 & {$[52]$} \\
\hline & Bechuana white & $2: 1,10$ & 62.7 & 72.7 & 87.3 & 12.9 & [82] \\
\hline \multirow{2}{*}{$\begin{array}{l}\text { Bambara } \\
\text { groundnut }\end{array}$} & NS & $1: 4,10$ & 65.6 & 93.2 & 130 & 25.21 & [76] \\
\hline & NS, Thailand & $1: 4,10$ & 71.7 & 75.3 & 79.2 & 11.73 & {$[54]$} \\
\hline
\end{tabular}




\begin{tabular}{|l|l|l|l|l|l|l|l|}
\hline $\begin{array}{l}\text { African } \\
\text { yambean }\end{array}$ & NS & $1: 4,10$ & 70.1 & 75.1 & 81.0 & 1.3 & {$[56]$} \\
\hline & & & & & & & \\
\hline $\begin{array}{l}\text { West African } \\
\text { locust bean }\end{array}$ & NS, Nigeria & 10 & 73.7 & 74.4 & 75.3 & 0.9 & {$[58]$} \\
\hline & NS & $\begin{array}{l}\text { Not mentioned, } \\
10\end{array}$ & 83.6 & 84.3 & & $6.56 .$. & {$[59]$} \\
\hline Tuber & & $3: 11.1,10$ & 74.2 & 79.1 & 87.4 & 17.8 & {$[23]$} \\
\hline $\begin{array}{l}\text { Zulu round } \\
\text { potato }\end{array}$ & Bola & Dik & 77.1 & 83.2 & 90.9 & 18.7 & \\
\hline
\end{tabular}

\# All varieties were Zimbabwe landraces except DC-75 and SV2

$T_{0}, T_{p}$ and $T_{e}=$ onset, peak and enset temperature from the gelatinisation endotherm

$\mathrm{NS}=$ not specified

There are no reported data for white fonio, black fonio, African rice and Livingstone potato 


\section{Thermal properties of African starches}

Table 4 shows the thermal properties of African starches. It should firstly be noted that the moisture content and the heating rate during analysis using differential scanning calorimetry (DSC) differ between the reported researches. These differences may affect the gelatinisation temperatures. Another less common and 'old' way to measure gelatinisation temperatures is the use of a Kofler hot stage. The gelatinisation is observed by the disappearance of Maltese crosses (birefringence) under a cross polarized light during heating. DSC uses the melting of the crystalline region as a measure for gelatinisation and is read from the endotherm of a DSC thermogram.

It is generally observed that the African legume starches have higher gelatinisation temperatures than starches from the African cereals (Table 4). The higher gelatinisation temperatures can be related to the higher crystallinity of the legumes compared to cereal starches (Table 3). Gelatinisation temperatures and enthalpies are good indicators of the temperature and energy required to gelatinize starches. This is important for cooking the starches for nutritional; and for biochemical reaction during processing, for example during beer brewing.

The reported gelatinisation temperatures of the starches (Table 4) can also be affected by various intrinsic factors and these are discussed below:

- The starches of the African cereal starches seem to be different from the commonly commercially cultivated cereals like wheat, rice and maize in terms of their thermal properties. Finger millet starches were found to have higher gelatinisation temperatures and higher enthalpy of gelatinisation compared to rice starches [40]. It was suggested that finger millet starches have stronger crystalline material compared to rice starches. Hoover et al. [73] also showed that pearl millet starches have higher gelatinisation temperatures than wheat and maize starches.

- Gelatinisation temperatures have been found to be positively correlated with phosphate content [30]. Cassava and potato starches to have higher phosphate 
content compared to not detectable phosphate for sorghum; and sorghum had lower gelatinisation temperatures compared to the others [30]. Thus, it is possible that the higher gelatinisation temperatures of the legume starches may also be related to their phosphate content.

- The amylose and amylopectin ratios are well known to affect the gelatinisation temperatures of starches. Waxy starches from sorghum have a broader gelatinisation temperatures and higher enthalpy than normal starches (Table 4) [29]. Waxy starches contain virtually no amylose, and this suggests that amylopectin structure mostly determines the gelatinisation temperatures. Amylopectin was also found to be positively correlated with the rate of retrogradation [29].

- Both genetic and environment factors were found to play a role in the thermal properties of starches from 10 sorghum genotypes cultivated in 4 different locations in Zimbabwe [83]. Starches extracted from corneous endosperm have higher gelatinisation temperatures than floury endosperm [11]. Although this is a genetic effect, the difference in terms of crystalline structure and amylopectin fine structure between the starches from floury and corneous endosperm from sorghum, are not known. Also presumably related to genetics, sorghum extracted from red sorghum was found to have higher gelatinisation temperatures than white sorghum [72]. However Beta et al. [11] found lower enthalpy for polyphenol-rich sorghum starches. This difference may lie in the extraction method as the work from Boudries et al. [72] used a mixture of hypochlorite and sodium hydroxide with a heating step $\left(60^{\circ} \mathrm{C}\right)$ for the red sorghum, whereas Beta et al. [11] only used sodium hydroxide at $5{ }^{\circ} \mathrm{C}$ for steeping.

- Amylopectin architecture may play a role in the gelatinisation temperature and enthalpy. Teff starches have been reported to have lower gelatinisation temperatures compared to maize starches [44]. The radius of gyration of amylopectin from five teff varieties was found to be an average of $156 \mathrm{~nm}$ compared to186 nm for maize starch [61]. The teff starches were also found to have shorter outer chain lengths of their amylopectin molecules compared to maize starch. Thus, it has been suggested that the shorter chain length and lower 
radius of gyration of amylopectin molecules can be related to the lower gelatinisation temperatures of teff starches [61].

\section{Rheological properties of African starches}

The rheological properties of starches are mainly in terms of pasting, viscosity and gelling. These properties are exhibited during wet heat processing of starches in excess water. Most rheological information is available on the pasting properties. Pasting properties are determined with equipment like the Brabender amylograph and the Rapid Visco Analyser (RVA).

Table 5 shows the pasting parameters of African starches. It is important to note that heating and cooling rate, holding temperatures and solid content will affect the pasting properties. Notwithstanding this, the pasting peak viscosity vary from about 250 to about 290 RVU (Rapid Visco Unit) for the African cereal starches and from about 120 to 290 $\mathrm{RVU}$ for African legumes. Pasting temperatures are about $65-75^{\circ} \mathrm{C}$ for African cereals compared to $76-83^{\circ} \mathrm{C}$ for African legumes.

Sang et al. [29] showed that sorghum waxy starches and heterowaxy starches (lower amylose than normal sorghum starch) had higher peak viscosity than normal sorghum starches. They suggested that amylose prevents swelling of starches during pasting by forming a barrier around the granules. These low amylose starches also had low setback viscosity and the authors suggest that amylose is important to forming a 3-dimensional network during cooling. Thus, as with the more commercial starches, amylose and amylopectin ratio also affects the pasting properties of the African starches.

Beta et al. [11] found that sorghum starch properties were affected by the polyphenol content in the grain. Higher polyphenol content seems to reduce the peak time to peak viscosity as well as produce a higher peak viscosity. Similarly Boudries et al. [72] found higher peak viscosity for red sorghum starches compared to white sorghum starches. 
Table 5. Pasting properties of starches from African cereals, legumes and tubers

\begin{tabular}{|c|c|c|c|c|c|c|c|c|c|}
\hline & Variety, Country & $\begin{array}{l}\text { Pasting } \\
\text { conditions }\end{array}$ & $\begin{array}{l}\text { Peak } \\
\text { viscosity }\end{array}$ & $\begin{array}{l}\text { Peak } \\
\text { time }\end{array}$ & $\begin{array}{l}\text { Pasting } \\
\text { temperature }\end{array}$ & $\begin{array}{l}\text { Breakdown } \\
\text { viscosity }\end{array}$ & $\begin{array}{l}\text { Set back } \\
\text { viscosity }\end{array}$ & $\begin{array}{l}\text { Final } \\
\text { viscosity }\end{array}$ & References \\
\hline \multicolumn{10}{|l|}{ Cereals } \\
\hline \multirow[t]{12}{*}{ Sorghum } & $\begin{array}{l}\text { White sorghum, } \\
\text { Algeria }\end{array}$ & \multirow{2}{*}{$\begin{array}{l}\text { Heat } 4.5^{\circ} \mathrm{C} \\
\text { /min to } 95^{\circ} \mathrm{C} \text {, } \\
\text { hold for } 10 \mathrm{~min} \\
\text {, cool to } 50^{\circ} \mathrm{C} \\
\text { and hold for } 10 \\
\text { min: about } 10 \\
\% \text { solid }\end{array}$} & 341 & 9.6 & 73.8 & 230 & 199 & 309 & \multirow[t]{2}{*}{ [72] } \\
\hline & $\begin{array}{l}\text { Red sorghum, } \\
\text { Algeria }\end{array}$ & & 394 & 8.5 & 74.7 & 279 & 185 & 299 & \\
\hline & M-35, India & $\begin{array}{l}\text { Heat } 12.1 \\
{ }^{\circ} \mathrm{C} / \mathrm{min} \text { to } 95 \\
{ }^{\circ} \mathrm{C} \text {, hold for } 2.5 \\
\mathrm{~min} \text {, cool to } 50 \\
{ }^{\circ} \mathrm{C} \text { and hold for } \\
2 \mathrm{~min} \text {, about } 10 \\
\% \text { solid }\end{array}$ & 339 & nd & 77.4 & 140 & nd & 343 & {$[80]$} \\
\hline & Katandanzara & \multirow{9}{*}{$\begin{array}{l}\text { Heat } 6^{\circ} \mathrm{C} / \mathrm{min} \\
\text { to } 95^{\circ} \mathrm{C} \text {, hold } \\
\text { for } 5 \mathrm{~min} \text {, cool } \\
\text { to } 50{ }^{\circ} \mathrm{C} \text { and } \\
\text { hold for } 1 \mathrm{~min} \text {, } \\
\text { about } 10 \% \\
\text { solid }\end{array}$} & $280-321$ & - & - & - & - & $228-287$ & \multirow[t]{9}{*}{ [83]\# } \\
\hline & Mutode & & $301-341$ & - & - & - & - & $212-274$ & \\
\hline & Chibonda & & $318-355$ & - & - & - & - & $225-276$ & \\
\hline & Chirimaugute & & $290-301$ & - & - & - & - & $236-306$ & \\
\hline & Kasvikisire & & $274-315$ & - & - & - & - & $237-279$ & \\
\hline & Mukadziusaenda & & $243-328$ & - & - & - & - & $217-288$ & \\
\hline & Mukadzidzoka & & $279-327$ & - & - & - & - & $201-250$ & \\
\hline & Tsveta & & $249-365$ & - & - & - & - & $216-251$ & \\
\hline & SV2 & & $256-316$ & - & - & - & - & $233-267$ & \\
\hline
\end{tabular}




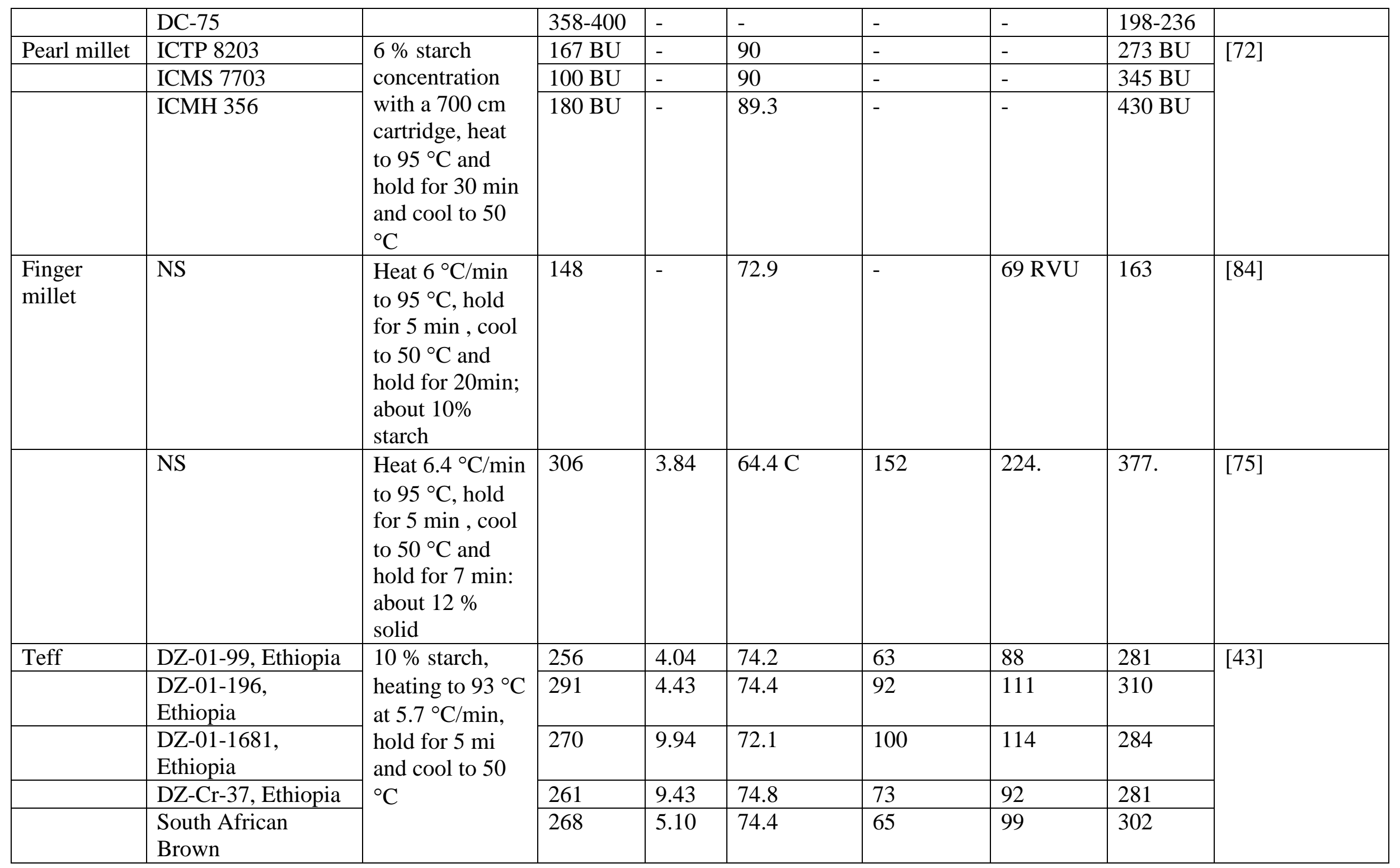




\begin{tabular}{|c|c|c|c|c|c|c|c|c|c|}
\hline White fonio & NS, Nigeria & $\begin{array}{l}8 \% \text { starch, Heat } \\
\text { to } 95^{\circ} \mathrm{C} \text {, and } \\
\text { hold for } 15 \\
\text { mina nd cool to } \\
50{ }^{\circ} \mathrm{C} \text { and hold } \\
\text { for } 15 \text { min }\end{array}$ & 790BU & & 76.8 & & & 740BU & [15] \\
\hline & A94, Nigeria & \multirow[b]{2}{*}{$\begin{array}{l}9 \% \text { starch, } \\
\text { heating rate of } 3 \\
{ }^{\circ} \mathrm{C} / \mathrm{min} \text { to } 92.5 \\
{ }^{\circ} \mathrm{C} \text {, hold for } 15 \\
\text { min and cool to } \\
40 \text { and hold for } \\
10 \text { min }\end{array}$} & 77 & 19.8 & - & - & - & 258 & \multirow[t]{2}{*}{ [47] } \\
\hline & A 85, Nigeria & & 85 & 18.9 & - & - & - & 24 & \\
\hline \multirow[t]{2}{*}{ Black fonio } & NS Nigeria & $\begin{array}{l}8 \% \text { starch,Heat } \\
\text { to } 95{ }^{\circ} \mathrm{C} \text {, and } \\
\text { hold for } 15 \\
\text { mina nd cool to } \\
50{ }^{\circ} \mathrm{C} \text { and hold } \\
\text { for } 15 \text { min }\end{array}$ & 660BU & - & 76.5 & - & - & $545 \mathrm{BU}$ & [15] \\
\hline & I85, Nigeria & $\begin{array}{l}9 \% \text { starch, } \\
\text { heating rate of } 3 \\
{ }^{\circ} \mathrm{C} / \mathrm{min} \text { to } 92.5 \\
{ }^{\circ} \mathrm{C} \text {, hold for } 15 \\
\text { min and cool to } \\
40 \text { and hold for } \\
10 \text { min }\end{array}$ & 78 & 18.5 & - & - & - & 160 & {$[47]$} \\
\hline \multicolumn{10}{|l|}{ legumes } \\
\hline Cowpea & NS, China & $\begin{array}{l}6 \% \text { starch } \\
\text { concentration, } \\
\text { heat from } 30 \text { to } \\
90{ }^{\circ} \mathrm{C} \text { at } 15\end{array}$ & 120 & - & 80.7 & - & 211 & - & [52] \\
\hline
\end{tabular}




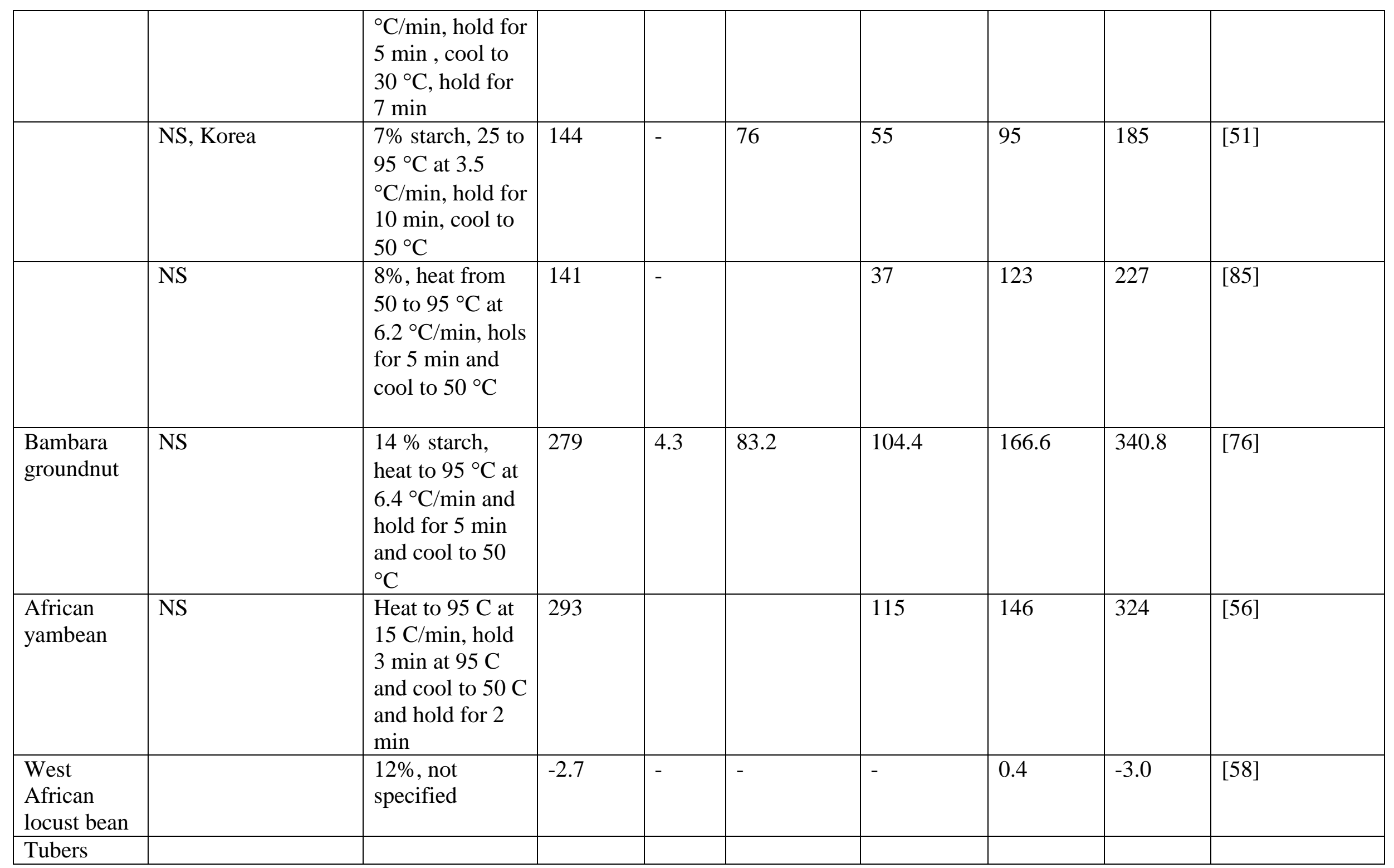




\begin{tabular}{|c|c|c|c|c|c|c|c|c|c|}
\hline Zulu round & Bola & $\begin{array}{l}7 \% \text { starch, heat } \\
\text { to } 95 \text { at } 6 \\
{ }^{\circ} \mathrm{C} / \mathrm{min} \text {, hold for } \\
5 \mathrm{~min} \text {, cool to } \\
50^{\circ} \mathrm{C} \text { and hold } \\
\text { for } 2 \mathrm{~min}\end{array}$ & 122 & 9.2 & 78 & 15 & 60 & 167 & [23] \\
\hline
\end{tabular}

- The values were divided by 12 to approximately convert $\mathrm{CP}$ to RVU

- Stirring is at $160 \mathrm{rpm}$ and starting temperature is $50 \mathrm{C}$, cooling rate is similar to heating rate

- \# All varieties were Zimbabwe landraces except DC-75 and SV2

- $\quad \mathrm{ND}=$ not determined

- NS =not specified

- No data for African rice and Livingstone potato

- Unit for Peak viscosity, Break down viscosity, Set back viscosity, and Final viscosity are RVU (unless otherwise specified as Brabender unit Land Peak time is min and pasting temperature is in ${ }^{\circ} \mathrm{C}$ 
These authors suggested that polyphenols may bind with starch to produce higher viscous pastes.

Various researchers have found that African cereal starches are different in their rheological properties from commercially available cereal starches such as maize, wheat or rice. Hoover et al. [73] found that pearl millet starches showed higher pasting viscosity than wheat and maize starches. They attributed the higher viscosity to higher bonding forces of pearl millet and suggested that pearl millet performed like cross-linked starches. Mohan et al. [40] also found finger millets starches to have higher pasting viscosity than rice starches and suggested that the difference was due to greater water binding capacity and granular rigidity of millet starches. Black and white fonio starches have been reported to have similar pasting properties to maize starch [47]. However, earlier research, Jideani and Akingbola [15] showed that black and white fonio starches to have lower peak and setback viscosity than maize starch. This is similar to teff starch, which was found to have lower pasting peak and setback viscosity compared to maize starch [44]. It was suggested that these may be related to the small granule size of teff starch. More recently it was suggested that the amylopectin architecture may also play a role [61].

Concerning the African legumes, African yambean starch was found to have a lower tendency to retrograde compared to pigeon pea and cowpea starches [50]. Huang et al. [52] found that cowpea had the higher pasting viscosity as well as the higher setback viscosity than chickpea and pigeon pea. The peak viscosity of cowpea starch was 2 times that of the chickpea and pigeon pea starches and the set back viscosity was almost 3-4 times higher. This was related to the lower amylose content, higher granule swelling and higher amount of amylopectin long chains of the cowpea starch.

Ihegwuagu et al. [58] showed that African locust bean starch did not paste compared to commercial maize starch. This could well have been due to the starch extraction procedure used by the authors, 3-5\% hypochlorite and 5\% sodium hydroxide solution at 
$\mathrm{pH} 9$ with incubation for $3 \mathrm{~h}$ at $100{ }^{\circ} \mathrm{C}$. Such conditions would gelatinise, paste and hydrolyse the starch.

There is limited information on the viscoelastic and gel properties of African starch pastes. Although pasting properties can provide a crude indication of the viscosity during cooling and heating, they do not provide the viscosity at different shear rates or the viscoelastic properties. This is important as several food processing conditionsare at different shear rates.

Amylose content plays an important role in determining the visco-elastic properties of sorghum starch pastes [29]. Waxy sorghum starch paste had a linear viscoelastic range up to $100 \%$ strain compared to $4 \%$ for normal starches. However, cooked normal starches were found to produce a firm standing gel with $\tan \delta$ value of less than 0.1 compared to a $\tan \delta$ value of about 0.1 for cooled waxy sorghum starch, which showed a very weak gel. The normal starch gel showed frequency independence of 1-100 rad/sec compared to frequency dependence for waxy and heterowaxy starches. These results show that normal sorghum starch can produce very good gels and that amylose plays a crucial role in gelling of sorghum starches.

In another study, Matalanis et al. [71] showed that cooked normal sorghum starches produce stronger gels compared to rice and maize starches. Further, rheological studies in terms of temperature sweeps at different storage days at $4{ }^{\circ} \mathrm{C}$ showed that amylose retrogradation was important for initial gel texture compared to amylopectin retrogradation, which is important over long-term storage. It also appears that sorghum starches had a higher content of long B chains of amylopectin and this may be related to higher retrogradation.

Cowpea starch has been shown to produce stronger gels than maize and potato starches, $\mathrm{s}$ with higher values for hardness, gumminess, chewiness and storage moduli for cooked cowpea starch [51].This suggests that cowpea starch forms a firm and strong gel. The frequency sweep over time showed that the storage and loss moduli was the highest for cowpea starch gels compared to potato and maize starch gels and the relative change with 
time was highest for cowpea. This suggests that cowpea starch had the highest rate of retrogradation and these authors [51] suggested the properties is related to greater length chain of amylose.

\section{Modification of African starches}

Starches are generally modified to improve their functionality. Limited studies are available to show the potential of modified African starches. Such studies should include physical modification like hydrothermal, high pressure processing, gamma irradiation and micronisation; and chemical methods like acetylation and oxidation. Novel ways to modify the functionality of these starches includes chemical interaction with other food material like fatty acids and hydrocolloids.

High pressure treatment (200-600 MPa) of sorghum starches can pre-gelatinise the starches as shown by loss of birefringence, but with maintenance of granular structure [79]. It was found that the high pressure treatment did not change the viscoelastic (temperature sweep) properties of the starches. This suggests that high pressure treatment can be a good processing technique to produce pregelatinised sorghum starch without changing the microstructure and the rheological properties. Another non-thermal treatment, $\gamma$-irradiation has shown to reduce the pasting peak, breakdown, final and setback viscosity of cowpea starch, but increased the gelatinisation temperatures with no change in granule morphology [85].

Acetylation of sorghum starches was shown to increase the swelling power and solubility, and decrease the gelatinisation temperature and enthalpy [80]. The peak paste viscosity, gel hardness and syneresis also decreased with acetylation. Similar results were also found for Bambara groundnut starch [55]. Acetylation as well as oxidation to produce acetylated and oxidised finger millet starches was found to increase the crushability and friability of the starches [75]. It was suggested that this modification is desirable for use as pharmaceutical excipient tablets. However, it was also found that the 
oxidised and acetylated finger millets starches had slightly higher gelatinisation temperatures and this was related by the authors to higher relative crystallinity.

Addition of xanthan gum to finger millet starch has shown to increase the gelling and retrogradation properties [86]. However, interaction with cassava starch reduced the retrogradation of finger millet starch. It was suggested that interaction of finger millet starch with other hydrocolloids can modify finger millet starch properties. Similarly, Alamri et al. [87] showed that extracted okra hydrocolloid can slow down the gelatinisation and reduced viscosity, setback and pseudoplasticity of sorghum starch.

Food grade chemicals like stearic acid have been shown to change the properties of teff starch [88, 89]. It was found that a small amount of stearic acid ( $<1.5 \% \mathrm{w} / \mathrm{w}$ of starch) can produce a high viscosity paste during heat processing for greater $30 \mathrm{~min}$. This high viscosity paste was non-gelling and can be used as a fat replacer in food systems. The high viscosity and non-gelling of the paste was attributed to the formation of amyloselipid complexes, as shown by ' $\mathrm{V}$ ' type crystalline structures with XRD and a melting of these crystallites at 100-120 C with DSC [89].

\section{Concluding remarks}

Starch is a major and important component of the cereals, legumes and tubers from Africa. However, information on their starches is very limited except for sorghum, millet and cowpea. Information about the starches from Livingstone potato is almost completely lacking. It is also difficult for these starches to achieve any economic importance when compared to maize, wheat, potatoes and cassava.

It is also important to note that the available information on the African starches relating to their physical, chemical and functional properties is incomplete and it is also very difficult to compare their properties due to different methodologies being employed by the various researchers. Further, the information on African starches also exclusively 
only concerns the native, unmodified starches and there is extremely limited information on their modification and food and non-food use applications, in comparison to commercial starches such as maize, cassava and potato.

The development of an industrial brewing and non-alcoholic malt beverage industry in Africa based on sorghum has been mentioned. Cereal food manufacture based on pearl millet is also expanding across the continent [90]. To ensure continuing growth of these industries, it is critical that sorghum and millet breeding programmes take into account the required starch characteristics.

Among the African starches reviewed in this paper, teff and cowpea starches have been shown to have some unusual and potential useful characteristics. The properties of teff starch in terms of very small granule size, absence of surface pores and unusual pasting properties has suggested that it can be used as a fat mimetic and in high shear applications $[14,88,89]$. The high degree of retrogradation of cowpea starch could be exploited in manufacture of gluten-free pasta and noodles to help maintain product texture.

To support Africa's rapidly expanding mining and industrial manufacturing sector, African starches should be also be investigated for non-food uses for applications such as adhesives, pharmaceutical excipients, sizing treatment, printing for paper manufacture and warp sizing and fabric printing for textile industry. Research for novel applications in the mining sector for fluid loss control in deep well drilling for oil and gas, and for purification of water [91] are also avenues for exploration.

The authors do not have any conflict of interest. 


\section{References}

1. Moorthy, S. N., Physicochemical and functional properties of tropical tubers: A review. Starch/Stärke 2002, 54, 559-592.

2. National Research Council, Lost Crops of Africa. Vol. 1: Grains, National Academy Press, Washington, DC, 1996.

3. National Research Council, Lost Crops of Africa. Vol. II:Vegetables, National Academy Press, Washington, DC, 2006.

4. Taylor, J. R. N., in: Wrigley, C, Corke, H., Walker, C. E., (Eds.), Encyclopedia of Grain Science, Elsevier, London, 2004, pp. 70-78.

5. Serna-Saldivar, S., Rooney, L. W., in: Dendy, D. A. V. (Ed.), Sorghum and Millets: Chemistry and Technology, American Association of Cereal Chemists, St. Paul, MN, 1995, pp. 69-124.

6. Dykes, L., Rooney, L. W., Sorghum and millet phenols and antioxidants. J. Cereal Sci. 2006, 44, 236-251.

7. Hill, H., Lee, L. S., Henry, R. J. Variation in sorghum starch synthesis genes associated with differences in starch phenotype. Food Chem. 2102, 131, 175-183.

8. Taylor, J. R. N. Emmambux, M. N. in: Hamaker, B. R. (Ed.), Technology of

Functional Cereal Products, Woodhead Publishing, Abington, UK, 2008, pp. 281-335

9. Taylor, J. R. N., Schober, T. J., Bean, S. R., Novel food and non-food uses for sorghum and millets. J. Cereal Sci. 2006, 44, 252-271.

10. Rooney, L. W., Waniska, R. D., in: Smith, C. W., Frederiksen, R. A. (Eds.), Sorghum: Origin, History, Technology, and Production, John Wiley \& Sons, New York, 2000, pp. 689-729.

11. Beta, T., Corke, H., Rooney, L. W., Taylor, J. R. N., Starch properties as affected by sorghum grain chemistry. J. Sci. Food Agric. 2000, 81, 245-251.

12. Obilana, A. B., Manyasa, E., in: Belton, P. S., Taylor, J. R. N. (Eds.), Pseudocereals and Less Common Cereals, Springer, Berlin, 2002, pp. 177-217.

13. Siwela, M., Taylor, J. R. N., De Milliano, W .A. J., Duodu, K. G., Occurrence and location of tannins in finger millet grain and antioxidant activity of different grain types. Cereal Chem. 2007, 84, 169-174.

14. Bultosa, G., Taylor, J. R. N., in: Wrigley, C, Corke, H., Walker, C. E., (Eds.), Encyclopedia of Grain Science, Elsevier, London, 2004, pp. 281-290. 
15. Jideani, A. I., Akingbala, J. O., Some physicochemical properties of acha (Digitaria exilis Stapf) and iburu (Digitaria iburua Stapf) grains. J. Sci. Food Agric. 1993, 63, 369374.

16. Gutiérrez-Uribe, J. A, Romo-Lopez, I., Serna-Saldívar, S. O., Phenolic composition and mammary cancer cell inhibition of extracts of whole cowpeas (Vigna unguiculata) and its anatomical parts. J. Functional Foods 2011, 3, 290-297.

17. Velasco, Z. I., Ana Rascón, A., Tovar, J., Enzymic availability of starch in cooked black beans (Phaseolus vulgaris L) and cowpeas (Vigna sp.). J. Agric. Food Chem. 1997, 45, 1548-1551.

18. Brough, S. H., Azam-Ali, S. N. The effect of soil moisture on the proximate composition of bambara groundnut (Vigna subterranea (L) Verdc). J. Sci. Food Agric. 1992, 60, 197-203.

19. Van Wyk, B.-E., Gericke, N., People's Plants: A Guide to Useful Plants of Southern Africa. Briza, Pretoria, 2002.

20 Oagile, O., Davey, M. R., Alderson, P. G., African yam bean: An under-utilized legume with potential as a tuber and pulse crop. J. Crop Improve. 2007, 20, 53-71.

21. Amoatey, J. M., Klu, G. Y. P., Bansa, D., Kumaga, F K., Aboagye, L. M., BenettLartey, S. O., Gamedoagbao, D. K., The African yam bean (Sphenostylis stenocarpa): A neglected crop in Ghana. West Afr. J. Appl. Ecol. 200, 1, 53-60.

22. Chukwu, O., Orhevba, B. A., Mahmood, B. I., Influence of hydrothermal treatments on proximate compositions of fermented locust bean (Dawadawa). J. Food Technol. 2010, 8, 99-101.

23. Jayakody, L., Hoover , R., Liu, Q., Weber, E., Studies on tuber and root starches. I. Structure and physicochemical properties of innala (Solenostemon rotundifolius) starches grown in Sri Lanka. Food Res. Int. 2005, 38, 615-629.

24. Leung, W.-T. W., Busson, F., Jardin, C., Food Composition Table for Use in Africa. FAO, Rome, 1968.

25. Allemann, J., Hammes. P. S., Chemical composition of South African Plectanthus esculentus tubers. S. Afr. J. Sci. 2003, 99, 127-129

26. Jane, J-L., Leas, K. S., Zobel, H., Robyt, J. F., Anthology of starch granule morphology by scanning electron microscopy. Starch/Stärke 1994, 46, 121-129.

27. Akingbala, J. O., Rooney, L. W., Palacios, L. G., Sweat, V. E., in: Rooney, L. W., Murty, D. S., (Eds.), International Symposium on Sorghum Grain Quality, ICRISAT, Patancheru, India,1982, pp. 251-262. 
28. Beta, T., Corke, H., Taylor, J. R. N., Effect of steeping treatment on pasting and thermal properties of sorghum starches. Cereal Chem. 2001, 78, 303-306.

29. Sang, U., Bean, S., Seib, P. A., Pedersen, J. Shi, Y.-C., Structure and functional properties of sorghum starches differing in amylose content. J. Agric. Food Chem. 2008, $56,6680-6685$.

30. Blennow, A., Bay-Smidt, A. M., Olsen, C. E., Møller, B. L., The distribution of covalently bound phosphate in the starch granule in relation to starch crystallinity. Int. $J$. Biol. Macromol. 2000, 27, 211-218.

31. Benmoussa, M., Suhendra, B., Aboubacar, A., Hamaker, B. R., Distinctive sorghum starch granule morphologies appear to improve raw starch digestibility. Starch/Stärke 2006, 58, 92-99.

32. Chung, J.-H., Han, J.-A., Yoo, B., Seib, P. A., Lim, S.-T., Effects of molecular size and chain profile of waxy cereal amylopectins on paste rheology during retrogradation. Carbohydrate Polymers 2008, 71, 365-371.

33. Malleshi, N. G., Desikachar, H. S. R., Tharananthan, R. N., Physico-chemical properties of native and malted finger millet, pearl millet and foxtail millet starches. . Starch/Stärke 1986, 38, 202-205.

34. Beleia, A., Varriano-Marston, E., Hoseney, R. C., Characterization of starch from pearl millets. Cereal Chem. 1980, 57, 300-303.

35. Hoover, R., Sosulki, F., Effect of cross-linking on functional properties of legume starches. Starch/Stärke 1986, 38, 149-155.

36. Singh, V., Ali, S. Z., Acid degradation of starch. The effect of acid and starch type. Carbohydrate Polymers 2000, 41, 191-195.

37. Madhusudhan, B., Tharanathan, R. N., Structural studies of linear and branched fractions of chickpea and finger millet starch. Carbohydrate Res. 1996, 284, 101-109.

38. Nirmala, M., Muralikrishna, G., Changes in starch during malting of finger millet (Ragi, Eleusine coracana, Indaf-15) and its in vitro digestibility studies using purified ragi amylases. Eur. Food Res. Technol. 2002, 215, 327-333.

39. Adebowalea, K. O., Afolabib, T. A., Olu-Owolabia, B. I., Hydrothermal treatments of Finger millet (Eleusine coracana) starch. Food Hydrocolloids 2005, 19, 974-983.

40. Mohan, B. H., Gopala, A., Malleshi, N. G., Tharanathan, R. N., Characteristics of native and enzymatically hydrolyzed ragi (Eleusine coracana) and rice (Oryza sativa) starches. Carbohydrate Polymers, 2005, 59, 43-50. 
41. McDonough, C. M., Rooney, L. W., Earp, C. F., Structural characteristics of Eleusine corocana (finger millet) using scanning electron and fluorescence microscopy. Food Microstruct. 1986, 5, 247-256.

42. Wankhede, D. B., Deshpande, H. W., Gunjal, B. B., Bhosale, M. B., Patil, H. B., Gahilod, A. T., Sawate, A. R., Walde, S. G., Studies on physicochemical, pasting characteristics and amylolytic susceptibility of starch from sorghum (Sorghum bicolor L. Moench grains. Starch/Stärke 1989, 41, 123-127.

43. Bultosa, G., Hall, A. N., Taylor, J. R. N., Physico-chemical characterization of grain tef (Eragrostis tef (Zucc.) Trotter) starch. Starch/Stärke 2002, 54, 461-468.

44. Bultosa, G., Taylor, J. R. N., Chemical and physical characterisation of grain tef (Eragrostis tef (Zucc.) Trotter) starch granule composition. Starch/Stärke 2003, 56, 304312.

45. Irving, D. W., Jideani, I. A., Microstructure and Composition of Digitaria exilis Stapf (acha): A Potential Crop. Cereal Chem. 1997, 74, 224-228.

46. Carcea, M., Acquistucci, R., Isolation and physicochemical characterization of fonio (Digitaria exilis Staph) starch. Starch/Stärke 1997, 49, 131-135.

47. Jideani, I. A., Takeda, Y., Hizukuri, S., Structures and physicochemical properties of starches from acha (Digitaria exilis), iburu (D. iburua), and tama (Eleusine corocana). Cereal Chem. 1996, 73, 677-685.

48. Taira, T., Uematsu, M., Nakano,Y, Morikawa, M., Molecular identification and comparison of the starch synthase bound to starch granules between endosperm and leaf blades in rice plants. Biochem. Genet. 1991, 29, 301-311.

49. Kishine, M., Suzuki, K, Nakamura, S., Ohtsubo, K., Grain qualities and their genetic derivation of 7 New Rice for Africa (NERICA) varieties. J. Agric. Food Chem. 2008, 56, 4605-4610.

50. Agunbiade, S. O., Longe, O. G., The physico-functional characteristics of starches from cowpea (Vigna unguiculata), pigeon pea (Cajanus cajan) and yambean (Sphenostylis stenocarpa). Food Chem. 1999, 65, 469-474.

51. Won, S.-Y., Choi, W., Lim, H. S., Cho, K.-Y., Lim, S.-T., Viscoelasticity of cowpea starch gels. Cereal Chem. 2000, 77, 309-314.

52. Huang, J., Schols, H. A., Van Soest, J. J. G., Jin, Z., Sulmann, E., Voragen, A. G. J., Physicochemical properties and amylopectin chain profiles of cowpea, chickpea and yellow pea starches. Food Chem. 2007, 101, 1338-1345. 
53. Enwere, N. J., Huang, Y.-C., Some chemical and physical properties of Bambara groundnut (Voandzeia subterranea Thouars) seed and products. Int J. Food Sci. Nutrit. 1996, 47, 469-475.

54. Sirivongpaisal, P., Structure and functional properties of starch and flour from bambarra groundnut. Songklanakarin J. Sci. Technol. 2008, 30, 51-56.

55. Adebowale, K. O., Lawal, O. S., Effect of annealing and heat moisture conditioning on the physicochemical characteristics of Bambarra groundnut (Voandzeia subterranea) starch. Nahrung/Food 2002, 46, 311-316.

56. Adebowale, K. O. Henle, T., Schwarzenbolz, U., Doert, T., Modification and properties of African yam bean (Sphenostylis stenocarpa Hochst. Ex A. Rich.) Harms starch I: Heat moisture treatments and annealing. Food Hydrocolloids 2009, 23, 19471957.

57. Agunbiade, S. O., The chemical composition and in vitro digestibility of yambean starch. Food Chem. 1998, 61, 173-176.

58. Ihegwuagu, N. E., Omojola, M. O., Emeje, M. O., Kunle, O. O., Isolation and evaluation of some physicochemical properties of Parkia biglobosa starch. Pure Appl. Chem. 2009, 81, 97-104.

59. Sankhon, A, Yao, W.-R., Amadou, I, Wang, H., Qian, H., Sangare, M., Influence of process conditions on digestibility of African locust bean (Parkia biglobosa) starch. Amer. J. Food Technol. 2012, 7, 552-561.

60. Muazu, J., Musa, H., Isah, A. B., Bhatia, R. G., Comparative tableting properties of three local potato starches. I. The glidant and binding properties. Amer. J. Pharmtech Res. 2012, 2, 434-447.

61. Bultosa, G., Hamaker, B. R., BeMiller J. N. An SEC-MALLS study of molecular features of water-soluble amylopectin and amylose of tef [Eragrostis tef (Zucc.) Trotter] starches. Starch/Stärke 2008, 60, 8-22.

62. Castro-Rosas, J., Bustos-Vázquez, Z. G., Palacios-Fonseca, A. J., Martínez, M. J. U., De la Cruz, G. V., Ramírez de León, J.A., Aldapa A.G. in: Vázquez, M., Ramírez de León, J.A., (Eds.), Sorghum: Food and Energy Source, Nova Science Publishers, New York, pp. 91-111.

63. Rooney, L. W., Miller, F. R., in: Rooney, L. W., Murty, D. S., (Eds.), International Symposium on Sorghum Grain Quality, ICRISAT, Patancheru, India,1982, pp. 143-162.

64. Sullins, R. D., Rooney, L. W., Microscopic evaluation of the digestibility of sorghum lines that differ in endosperm characteristics. Cereal Chem. 1974, 51, 134-142. 
65. Lawal, O. S., Lapasin, R, Bellich, B., Olayiwola, T. O., Cesàro, A., Yoshimura, M., Nishinari, L., Rheology and functional properties from five improved rice varieties from West Africa. Food Hydrocoll. 2011, 25, 1785-1792.

66. Hoseney, R. C. Principles of Cereal Science and Technology, $2^{\text {nd }}$ ed., American Association of Cereal Chemists, St. Paul, MN, 1994.

67. Fannon, J. E., Hauber, R. J., BeMiller, J. N., Surface pores of starch granules. Cereal Chem. 1992, 69, 284-288.

68. Huber, K. C., BeMiller, J. N., Visualization of channels and cavities of corn and sorghum starch granules. Cereal Chem. 1997, 74, 537-541.

69. Bultosa, G., Taylor, J. R. N., Paste and gel Properties and in vitro digestibility of tef [Eragrostis tef (Zucc.) Trotter] starch. Starch/Stärke 2004, 56, 20-28.

70. Donald, A. M., in: Eliasson, A. C. (Ed.), Starch in Food: Structure, Function and Applications, Woodhead Publishing/CRC Press, Cambridge, UK/New York, 2004 pp. 156-184.

71. Matalanis, A. M., Campanella, O. H., Hamaker, B. R., Storage retrogradation behaviour of sorghum, maize and rice starch pastes related to amylopectin fine structure. J. Cereal Sci., 2009, 50, 74-81.

72. Boudries, N., Belhaneche, N., Nadjemi, B., Deroanne, C. et al. Physicochemical and functional properties of starches from sorghum cultivated in the Sahara of Algeria. Carbohydr. Polym. 2009, 78, 475-480.

73. Hoover, R., Swamidas. G., Kok, L. S., Vasanthan, T., Composition and physicochemical properties of starch from pearl millet grains. Food Chem. 1996, 56, 355367.

74. Dharmaraj, U., Parameswara, P., Somashekar, R., Malleshi, N. G., Effect of processing on the microstructure of finger millet by X-ray diffraction and scanning electron microscopy. J. Food Sci. Technol. 2011 (in press DOI 10.1007/s13197-0110536-4)

75. Afolabi, T. A., Olu-Owolabi, B. I., Adebowale, K. O., Lawal, O. S., Akintayo, C. O., functional and tableting properties of acylated finger millet (Eleusine coracana) starch. Starch/Stärke 2012, 64, 326-337.

76. Afolabi, T. A., Synthesis and physicochemical properties of carboxymethylated Bambara groundnut (Voandzeia subterranean) starch. Int. J. Food Sci. Techol. 2012, 47, 445-451. 
77. Hoover, R., and Vasanthan, T., Effect of heat-moisture treatment on the structure and physicochemical properties of cereal, legume, and tuber starches. Carbohydr. Res. 1994, 252, 33-53

78. Gunaratne, A., Hoover, R. Effect of heat-moisture treatment on the structure and physicochemical properties of tuber and root starches. Carbohydr. Polym. 2002, 49, 425437.

79. Vallon, K. J. R., Arendt, E. K., Effects of high pressure and temperature on the structural and rheological properties of sorghum starch. Innovative Food Sci. Emerging Technol. 2009, 10, 449-456.

80. Singh, H., Sodhi, N. S., Singh, N., structure and functional properties of acetylated sorghum starch. Int. J. Food Prop. 2012, 15, 312-325

81. Jideani, V. A., Scott, D. J., Hydrothermal characteristics of pearl millet (pennisetum glaucum) flour during cooking into 'fura'. African J Agric. Res. 2012, 7, 2751-2763.

82. Mwangwela, A. M., Waniska, R. D., Minnaar, A., Effect of micronisation temperature (130 and $170{ }^{\circ} \mathrm{C}$ ) on functional properties of cowpea flour. Food Chem. 2007, 104, 650-657.

83. Beta, T., Corke, H., Genetic and environmental variation in sorghum starch properties. J. Cereal Sci. 2001, 34,261-268.

84. Mangala, S. L., Malleshi, N. G., Mahadevamma, Tharanathan, R. N., Resistant starch from differently processed rice and ragi (finger millet). Eur. Food Res. Technol. 1999, 209, 32-37.

85 Abu, J. O., Duodu, K. G., Minnaar, A., Effect of $\gamma$ - irradiation on some physicochemical and thermal properties of cowpea (Vigna unguiculata L. Walp) starch. Food Chem. 2006, 95, 386-393.

86. Ojijo, K. O., Shimoni, E., Influence of xanthan gum and tapioca starch on the retrogradation and gelation of finger millet (Eleusine coracana L. Gaertner) starch pastes. J. Texture Stud. 2007, 38, 100-115

87. Alamri, M. S., Mohamed, A. A., Hussein, S., Effect of okra gum on pasting, thermal, and viscous properties of rice and sorghum starches. Carbohydr. Polym. 2012, 89, 199207.

88. D’Silva, T. V., Taylor, J. R. N., Emmambux, M. N., Enhancement of the pasting properties of teff and maize starches through wet-heat processing with added stearic acid. J. Cereal Sci. 2011, 53, 192-197 
89. Wokadala, O. C., Ray, S. S., Emmambux, M. N., Occurrence of amylose-lipid complexes in teff and maize starch biphasic pastes. Carbohydr. Polym. 2012, 90, 655660.

90. Taylor, J. R. N., Barrion, S. C., Rooney, L. W., Pearl millet - New developments in an ancient food grain. Cereal Foods World 2010, 55, 16-19.

91. Kraak A., Industrial applications of potato starch products. Indust. Crops Products 1993, 1,107-112 